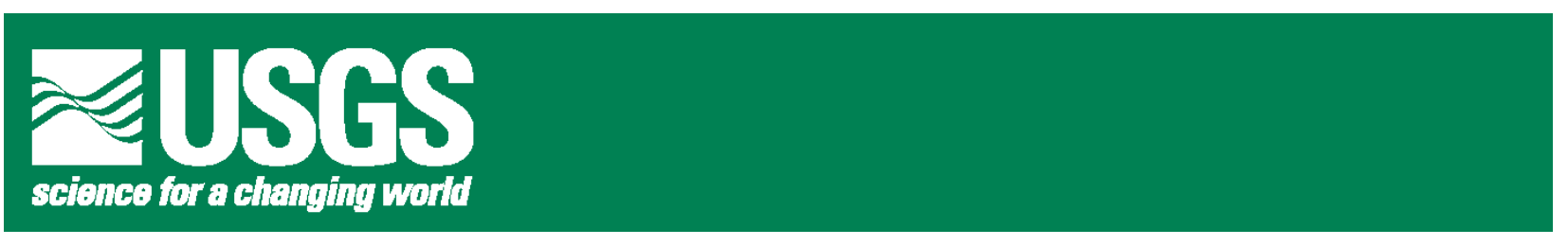

\title{
A Review of Recently Active Faults in Taiwan
}

by M.G. Bonilla ${ }^{1}$

Open-File Report 75-41

Version 1.1

1975

Prepared in cooperation with

National Science Council of Republic of China

and

U.S. Atomic Energy Commission

Available on the Web at http://geopubs.wr.usgs.gov/open-file/of75-41/

This report is preliminary and has not been reviewed for conformity with U.S. Geological Survey editorial standards. Any use of trade, product, or firm names is for descriptive purposes only and does not imply endorsement by the U.S. Government.

\section{U.S. DEPARTMENT OF THE INTERIOR U.S. GEOLOGICAL SURVEY}

${ }^{1} 345$ Middlefield Road, Menlo Park, CA 94025 


\section{Version History}

Version History for: Bonilla, M.G., 1975, A review of recently active faults in Taiwan: U.S. Geological Survey Open-File Report 75-41, 42 p.

Version 1.1 - October 17, 1999

Doc Bonilla scanned the original typewriter pages and illustrations and did OCR on the text. Minor typographical errors were corrected. Mike Diggles, laid out PostScript-font text and TIF files in Adobe PageMaker, produced a Portable Document Format (PDF) file, and added bookmarks and thumbnails. The PDF and an HTML front-end are available on the Web at http:// geopubs.wr.usgs.gov/open-file/of75-41/

Version $1.0-1975$

First release in paper form printed by the U.S. Government Printing Office: 1975-0-689-906/16 


\section{Contents}

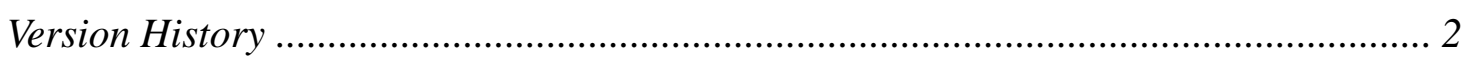

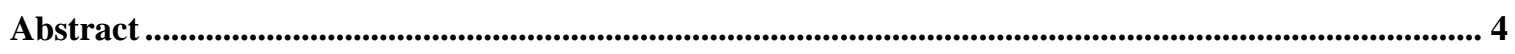

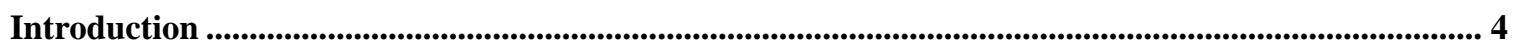

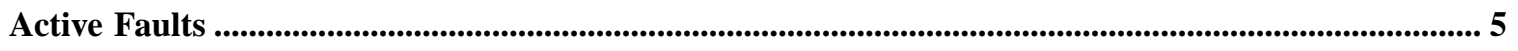

Historically Active Faults.......................................................................................................... 6

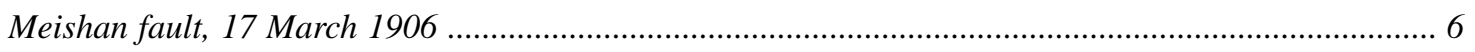

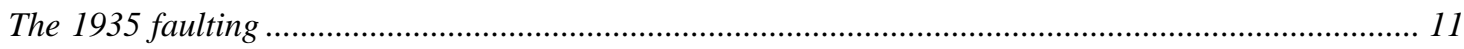

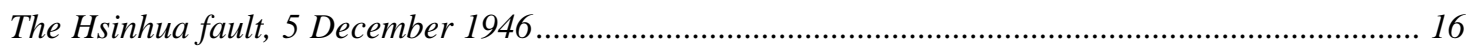

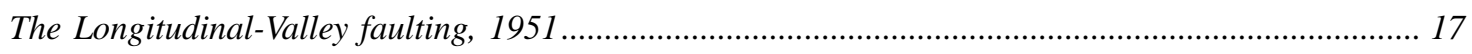

Faults That Cut Holocene or Pleistocene Deposits ................................................................................................. 22

Possible Fault Creep ............................................................................................................................ 30

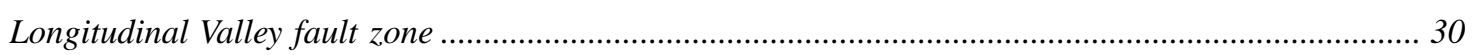

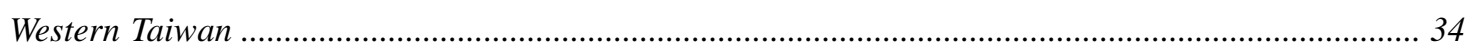

Tectonic Uplift and Subsidence

Summary and Conclusions ..................................................................................................................... 38

References cited ................................................................................................................................................. 40

\section{Illustrations}

\begin{tabular}{|l|l}
\hline Figure 1 \\
\hline Figure 2
\end{tabular}

Table

Table 1. Approximate long-term minimum uplift rates .............................................. 18 


\section{Abstract}

Six faults associated with five large earthquakes produced surface displacements ranging from 1 to $3 \mathrm{~m}$ in the period 1906 through 1951. Four of the ruptures occurred in the western coastal plain and foothills, and two occurred in the Longitudinal Valley of eastern Taiwan. Maps are included showing the locations and dimensions of the displacements. The published geological literature probably would not lead one to infer the existence of a fault along most of the 1906 rupture, except for descriptions of the rupture itself. Over most of its length the 1935 rupture on the Chihhu fault is parallel to but more than $0.5 \mathrm{~km}$ from nearby faults shown on geologic maps published in 1969 and 1971; only about $1.5 \mathrm{~km}$ of its $15 \mathrm{~km}$ length coincides with a mapped fault. The coastal plain part of the Tuntzuchio fault which ruptured in 1935 is apparently not revealed by landforms, and only suggested by other data. Part of the 1946 Hsinhua faulting coincides with a fault identified in the subsurface by seismic work but surface indications of the fault are obscure. The 1951 Meilun faulting occurred along a conspicuous pre-1951 scarp and the 1951 Yuli faulting occurred near or in line with pre-1951 scarps.

More than 40 faults which, according to the published literature, have had Pleistocene or later movement are shown on a small-scale map. Most of these faults are in the densely-populated western part of Taiwan. The map and text calls attention to faults that may be active and therefore may be significant in planning important structures.

Equivocal evidence suggestive of fault creep was found on the Yuli fault and the Hsinhua fault. Fault creep was not found at several places examined along the 1906 fault trace.

Tectonic uplift has occurred in Taiwan in the last 10,000 years and application of eustatic sea level curves to published radiocarbon dates shows that the minimum rate of uplift is considerably different in different parts of the island. Incomplete data indicate that the rate is high near Hualien, where an uplift of at least $0.6 \mathrm{~m}$ and probably more than $1 \mathrm{~m}$ occurred in the 1951 earthquake, and near and south of the 1946 faulting. Sudden uplifts can have serious consequences for installations near the shore. Investigation of this process, study of recently active faults, and continuing study of seismicity are necessary parts of a practical earthquake-hazard reduction program.

\section{Introduction}

The study of active faults and earthquake history provides a basis for anticipating the location and size of future earthquakes and related phenomena such as surface faulting, landslides, and other ground failures. Taiwan has had and will continue to have many strong earthquakes. During the twentieth century more than 20 earthquakes have resulted in human deaths, and during a 45-year period starting in 1906 faulting ruptured the ground surface at six places. Taiwan is thus a place where earthquakes and faulting should be studied to minimize death and destruction, and where knowledge about these geologic processes can be gained for general application throughout the world.

This paper summarizes scattered information, some of which is out of print or unpublished, on recently active faults in Taiwan. In addition to a rather full treatment of historic 
faulting, the paper calls attention to faults that cut Holocene and Pleistocene deposits and discusses evidence related to fault creep and vertical tectonic movements. Some reinterpretations and inferences are made on the basis of the available information.

The paper is based on a review of the literature done intermittently during the last few years supplemented by a field reconnaissance, a rapid stereoscopic examination of aerial photographs of a few areas, and discussions with many Chinese geologists during a six-week study period in January and February, 1973. The study in Taiwan was done for two purposes: to help initiate geologic studies in the recently formed Chinese Earthquake Research Center and to gather data for a study of worldwide historic surface faulting in which the writer was engaged. The work in Taiwan was supported by the National Science Council of the Republic of China and the United States Geological Survey; the literature study was supported by the United States Atomic Energy Commission and the U.S. Geological Survey.

The work in Taiwan was greatly facilitated by many individuals and organizations. Mr. T.H. Yao of the National Science Council participated in all of the field reconnaissance, recognized the 1906 fault scarp and the Houchiali scarp, served as interpreter, arranged meetings with Chinese scientists, arranged for access to aerial photographs, and used his extensive knowledge of Taiwan geography, geology, and culture to make the writer's trip pleasant and useful. His participation is also acknowledged at appropriate points in the text. Dr. C. Y. Meng of the Chinese Petroleum Corporation arranged a field trip in western Taiwan, organized meetings with geologists and geophysicists, provided publications, and extended gracious and friendly hospitality. Mr. H. P. Lueng of the Chinese Earthquake Research Center participated in some of the field work and was the first to see the cracks suggestive of fault creep near the 1946 fault. C. C. Biq and T. L. Hsu of the Geological Survey of Taiwan, C. C. Lin and others of the National Taiwan University, and personnel of the Taiwan Power Company, the Tsengwen Reservoir Development Commission, and the Mining Research and Service Organization were generous in supplying publications, information, and other kinds of support. Colleagues in the U.S. Geological Survey in Menlo Park, A. T. F. Chen and C. Y. King translated parts of Chinese reports and L. A. Hodgen drafted nearly all of the illustrations. The writer extends his sincere thanks and appreciation to all of these individuals and organizations.

\section{Active Faults}

Active faults are important for several reasons. Sudden displacements on active faults are the usual cause of earthquakes, and the intensity of the earthquake vibrations at a particular place is partly controlled by the distance to the fault (or source of the earthquake). In addition to damage from earthquake shaking, the displacement on the fault sometimes reaches the ground surface and causes rupture and differential movement that may be as much as several meters. The surface displacements can be expected to severely damage manmade structures that are across the fault unless they are of such nature that they can withstand the differential movements.

An active fault can be defined as one that has moved in the recent past and may move in the near future; that is, it may move again within a time span that is important to humans. The recognition of an active fault is commonly based on estimating the time of last movement. A conservative set of criteria for identifying a fault capable of causing surface faulting is that used by the U.S. Atomic Energy Commission (1973) in siting nuclear reactors. Those criteria consider a 
fault capable of producing faulting at the surface if it shows one or more of the following: 1) one movement at or near the ground surface in the last 35,000 years; 2) more than one movement at or near the ground surface in the last 500,000 years; 3) evidence for displacement of geomorphic features (in the absence of absolute dates); 4) instrumentally well-determined seismicity on the fault; and 5) a relationship to a capable fault identified by the above characteristics such that movement on one could reasonably be expected to cause movement on the other. Faults that have ruptured the surface in historic time or displaced Holocene deposits (about 10,000 years old) clearly are active according to criterion number 1 above; such faults on Taiwan are among those shown on figure 1 and discussed in following sections of this paper.

Faults that cut Pleistocene deposits (between 10,000 and 3 million years old) may or may not be active according to the criteria listed above. If the deposits are of late Pleistocene age, the fault may fit criterion number 1 or number 2 . Where the youngest deposits along a fault are of early Pleistocene age, the fault could have moved at any time since accumulation of the deposits, including Holocene time or historic time, and leave no trace except geomorphic features. In a land of high rainfall and intensive cultivation such as Taiwan, geomorphic evidence of faulting can be quickly modified or obliterated. Subtle geomorphic evidence of faulting can be easily missed if the investigator is not specifically looking for such evidence.

Thus, many of the faults shown on figure 1 probably are active, and all of them may be active, according to the criteria listed above. Criterion number 4, seismicity, has been used only to a small extent to identify active faults because precisely located focal data have not yet been acquired for most of Taiwan.

\section{Historically Active Faults}

Faults that have ruptured the ground surface in Taiwan during historic time and are reported in the geologic literature are described in this section. Six faults associated with five large earthquakes from 1906 to 1951 produced surface displacements ranging from 1 to $3 \mathrm{~m}$. Four of the ruptures occurred in the coastal plain and foothills of western Taiwan and two occurred in the Longitudinal Valley of eastern Taiwan. The fault ruptures are described in chronological order.

\section{Meishan fault, 17 March 1906}

This fault rupture in western Taiwan (no. 26, fig. 1) was associated with a magnitude 7.1 earthquake that killed 1,258 people and destroyed more than 6,000 houses (Omori, 1907; Iida, 1959, p. 100). The rupture was called the Baishiko fault by Omori and referred to as the Meitzukeng fault by Bonilla and Buchanan (1970); however those place names are not shown on most modern Chinese maps and the name Meishan fault is adopted here. The name refers to the town of Meishan (in Chiai County) which lies about $1 \mathrm{~km}$ from the east end of the 1906 rupture (fig. 2). The fault trends $\mathrm{S}^{\circ} 5^{\circ} \mathrm{W}$ over most of its length but toward the west it trends $\mathrm{S} 53^{\circ} \mathrm{W}$ and then extends nearly due west to Minhsiungchen. The straight-line distance between the mapped ends of the 1906 rupture is about $13 \mathrm{~km}$. The rupture was longer, however, and extended an unknown distance into the mountainous area to the east which was not examined by Omori. The west-trending segment may have continued in the subsurface $12 \mathrm{~km}$ farther west of the surface trace, where large quantities of sand and water issued from fissures (Omori, 1907, p. 58-59). 


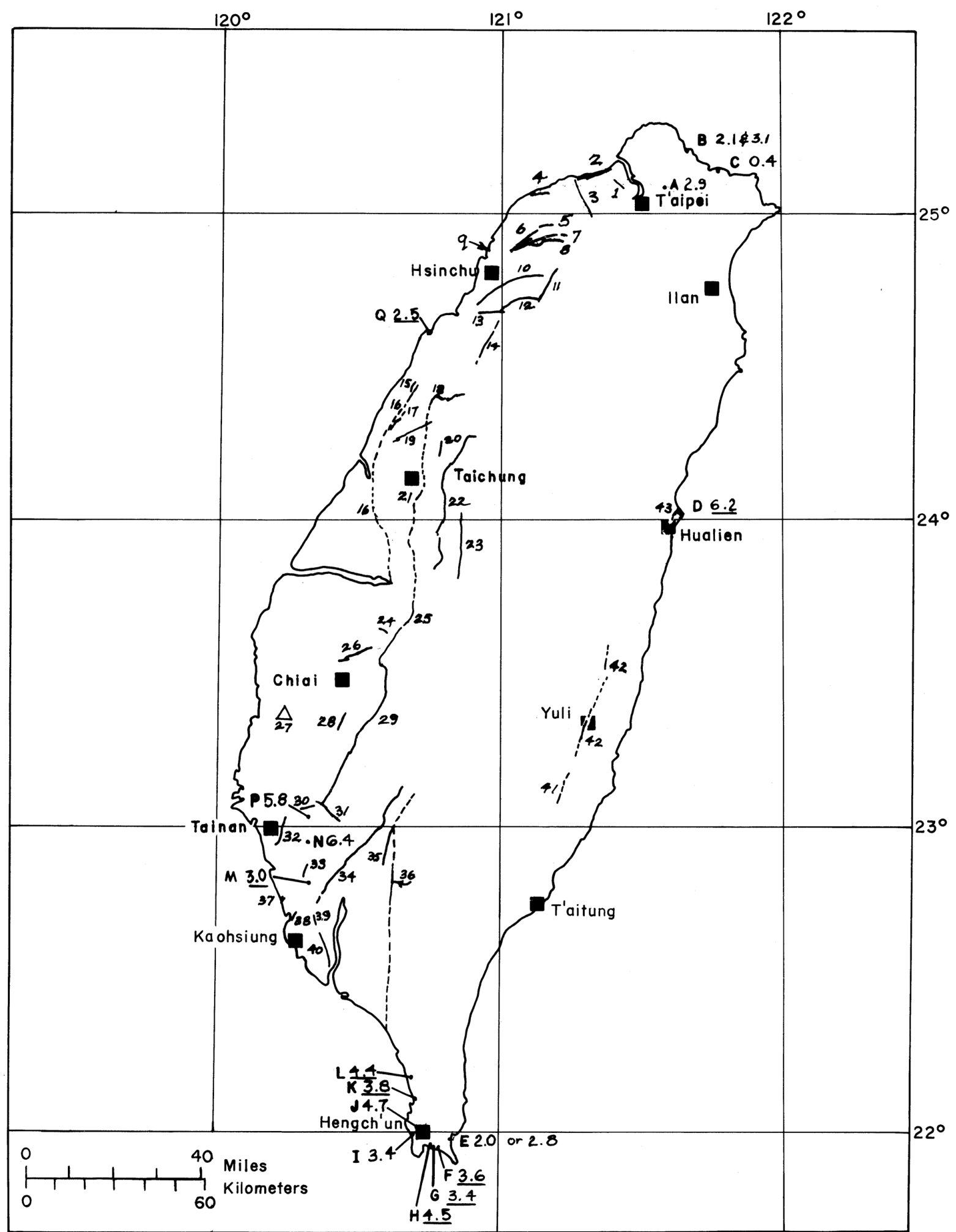

Figure 1. Map of Taiwan showing historic surface faulting, faults that cut Holocene or Pleistocene deposits, and minimum rates of uplift. The historic surface ruptures are numbered 14, 19,26, 30, 42, and 43; see text for age of deposits cut by other faults. Minimum rates of Holocene uplift (in $\mathrm{mm} / \mathrm{yr}$.) are given for localities A through Q; underlined values are averages for the locality. 


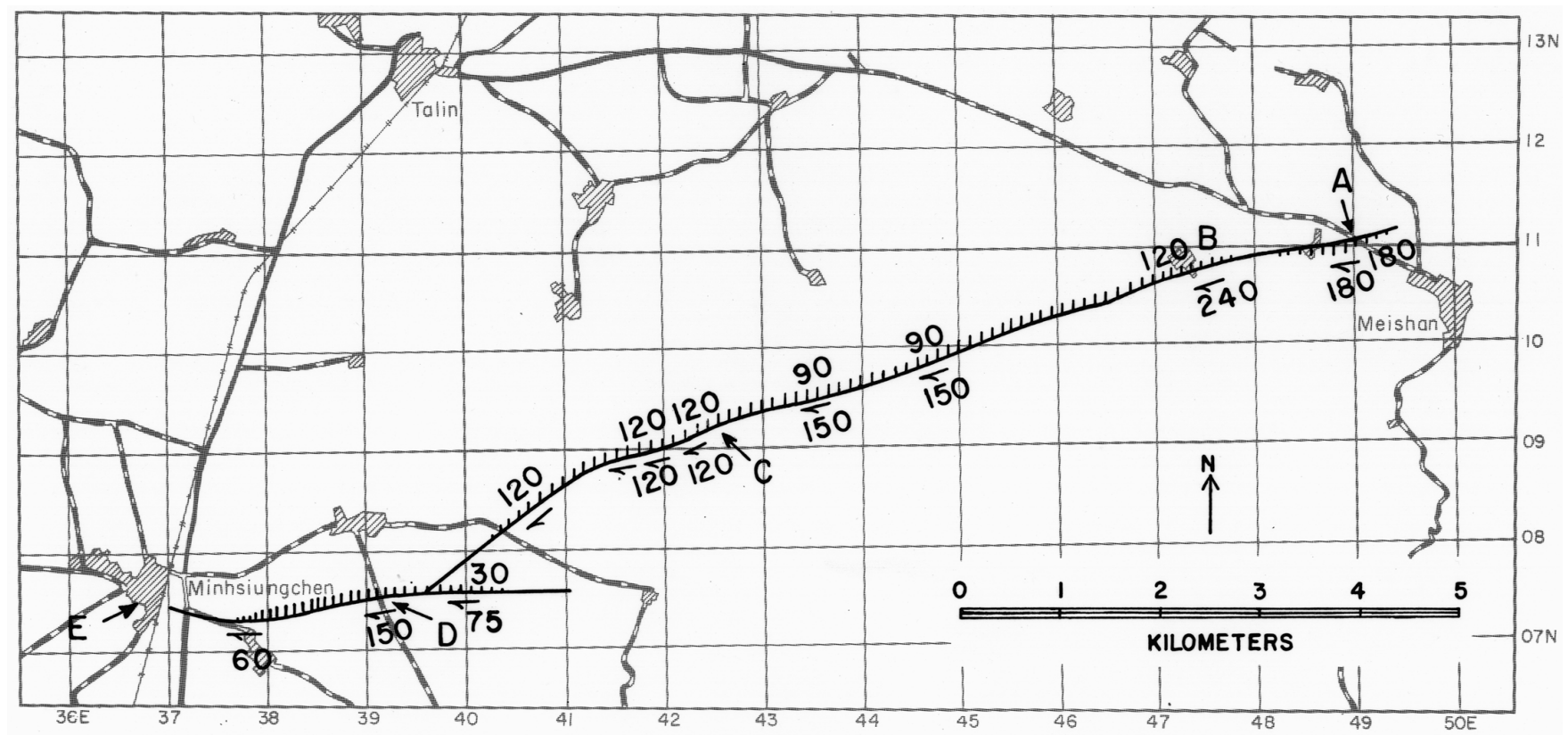

Figure 2. Map showing location and displacements on the 1906 Meishan fault trace, after Omori (1907). Displacements given in centimeters; numbers with arrows indicate horizontal displacements. Numbers without arrows indicate vertical displacement; barbs on downthrown side. Letters show localities discussed in text.

Open fissures in that area, shown in photographs published by Gagel (1912), may have been caused by faulting but more likely were caused by the superficial process called "liquefaction."

Maximum component of right slip in 1906 was $2.4 \mathrm{~m}$ at a point near the east end of the fault where $1.2 \mathrm{~m}$ of vertical displacement also occurred, yielding a calculated oblique slip of 2.7 $\mathrm{m}$. At this point and southwest of it the north side of the fault was relatively lowered, but on the short segment northeast of this point the south side of the fault was relatively lowered. The maximum vertical displacement of $1.8 \mathrm{~m}$ occurred near the northeast end, combined with a right slip of $1.8 \mathrm{~m}$.

The writer accompanied by T. H. Yao and C.H. Wang looked briefly at the Meishan fault at several places (A-E, fig. 2). The south-facing part of the 1906 scarp was still visible in 1973 near Meishan (west of point A, fig. 2) but it has been artificially modified and is only about half as high as it was in 1906 on the west side of the highway (fig. 3) and we could not see it in the fields on the east side of the highway. We could not find the scarp at point $\mathrm{C}$, in the vicinity of which Omori (1907) reported vertical displacement of about $1.2 \mathrm{~m}$. The position of the fault near point $\mathrm{D}$ is uncertain but it may be where the road rises a few meters to the south coincident with a change from brown coarse gravel on the north to compact reddish brown lateritic(?) silty clayey sand on the south. Omori (1907, fig. 2) shows a vertical displacement of only about $30 \mathrm{~cm}$ for this east-west part of the fault. If the present differences in elevation and in materials north and south of point D are the result of faulting, which is likely, they indicate pre-1906 movement on the Meishan fault.

The Meishan fault is particularly interesting because the published geologic literature (except for descriptions of the 1906 rupture itself) probably would not lead one to infer the 


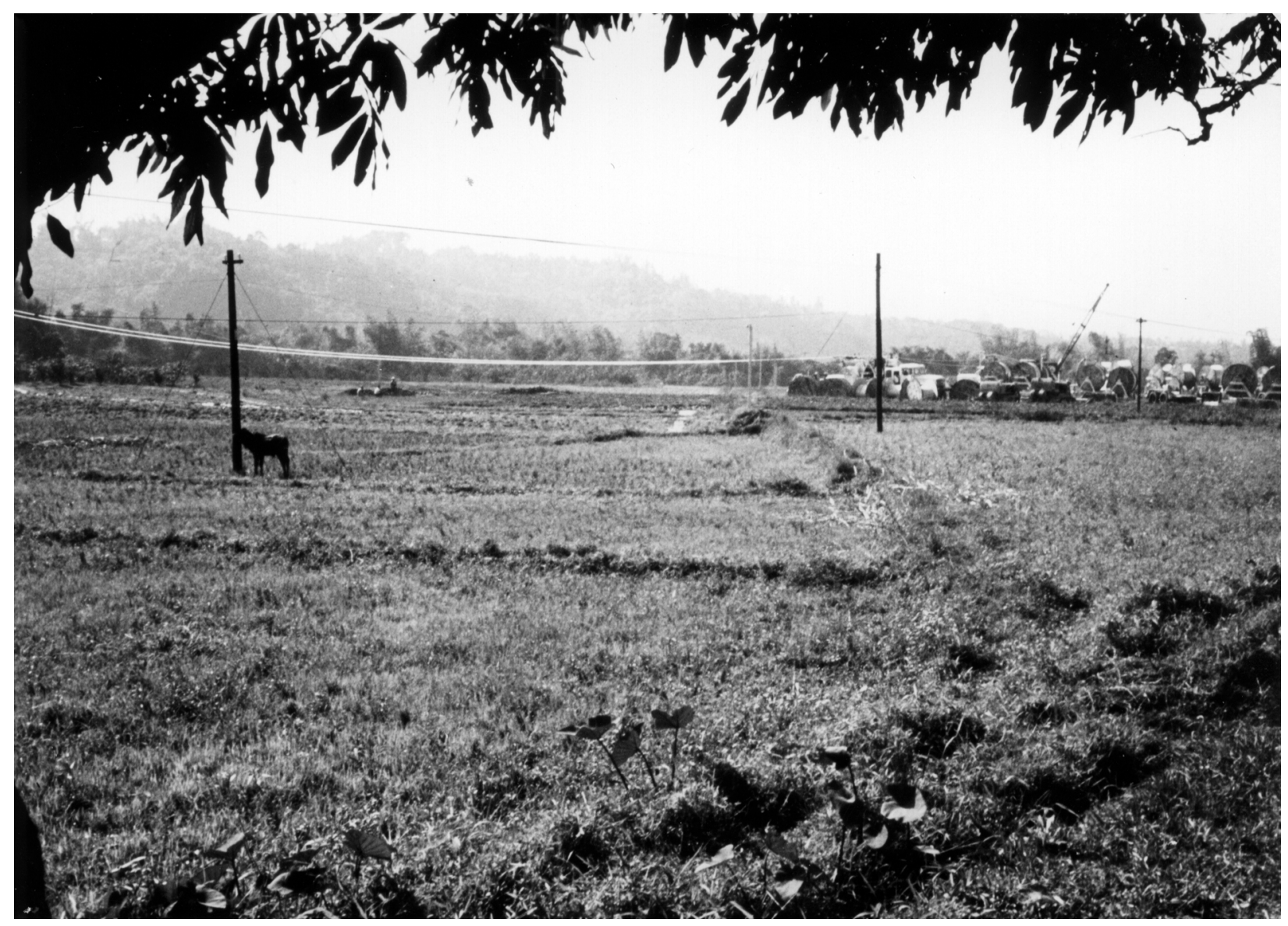

Figure 3. View westward along 1906 fault scarp about $1 \mathrm{~km}$ northwest of Meishan. Vertical displacement of $1.8 \mathrm{~m}$ and right slip of $1.8 \mathrm{~m}$ occurred in this vicinity in 1906. Photo taken in January 1973

existence of the fault over most of its length. Because of interest in developing petroleum production, considerable work has been done in the area including geologic mapping, photogeology, geophysics, and some drilling. None of these techniques identified a fault that coincides with the 1906 rupture, but sets of faults were identified by geophysical means that have similar trends (fig. 4). The geologic structures near the middle and eastern parts of the 1906 trace, however, trend generally northward. The geologic map of western Taiwan (Chinese Petroleum Corporation, 1971) shows anticlinal structures trending north-northeast in the vicinity of Meishan and a large reverse fault trending north-northeast about $4 \mathrm{~km}$ east of Meishan.

Several things suggest that investigations whose goal was to search for recent faulting rather than to find petroleum possibly could have led to suspicion of a fault where the 1906 rupture occurred: 1) the topographic and lithologic evidence near Point D, (fig. 2) and the geophysical evidence for east-west faults, mentioned above, 2) the Chinese Petroleum Corporation (1971) geologic map shows a contact between two Pleistocene formations that essentially coincides with the 1906 trace for about $3 \mathrm{~km}$; 3) a south- facing scarp identified as a stream scarp by Sun (1971, fig. 2) is nearly coincident with the north-facing 1906 trace for $0.8 \mathrm{~km}$; 4) a brief examination by the writer of a few aerial photographs showed lines of vegetation and linear gaps in timbered areas that are parallel to and in the same general location as the 1906 trace in places between points B and C of figure 2; and 5) the front of the hilly region as shown on the photogeologic map of Sun (1971, fig. 
1) has a southward trend north of Meishan but turns westward to extend for about $14 \mathrm{~km}$ from Meishan and, except for a $2.5 \mathrm{~km}$ segment, lies just south of the 1906 trace. Sun (1971, p. 70) used a similar change in trend of the hill front as a partial basis for inferring the east-trending Chutzuchiao fault some $20 \mathrm{~km}$ to the south. Thus the geological information currently available (aside from knowledge of the 1906 rupture itself) includes suggestive but not compelling evidence for the existence of the Meishan fault.
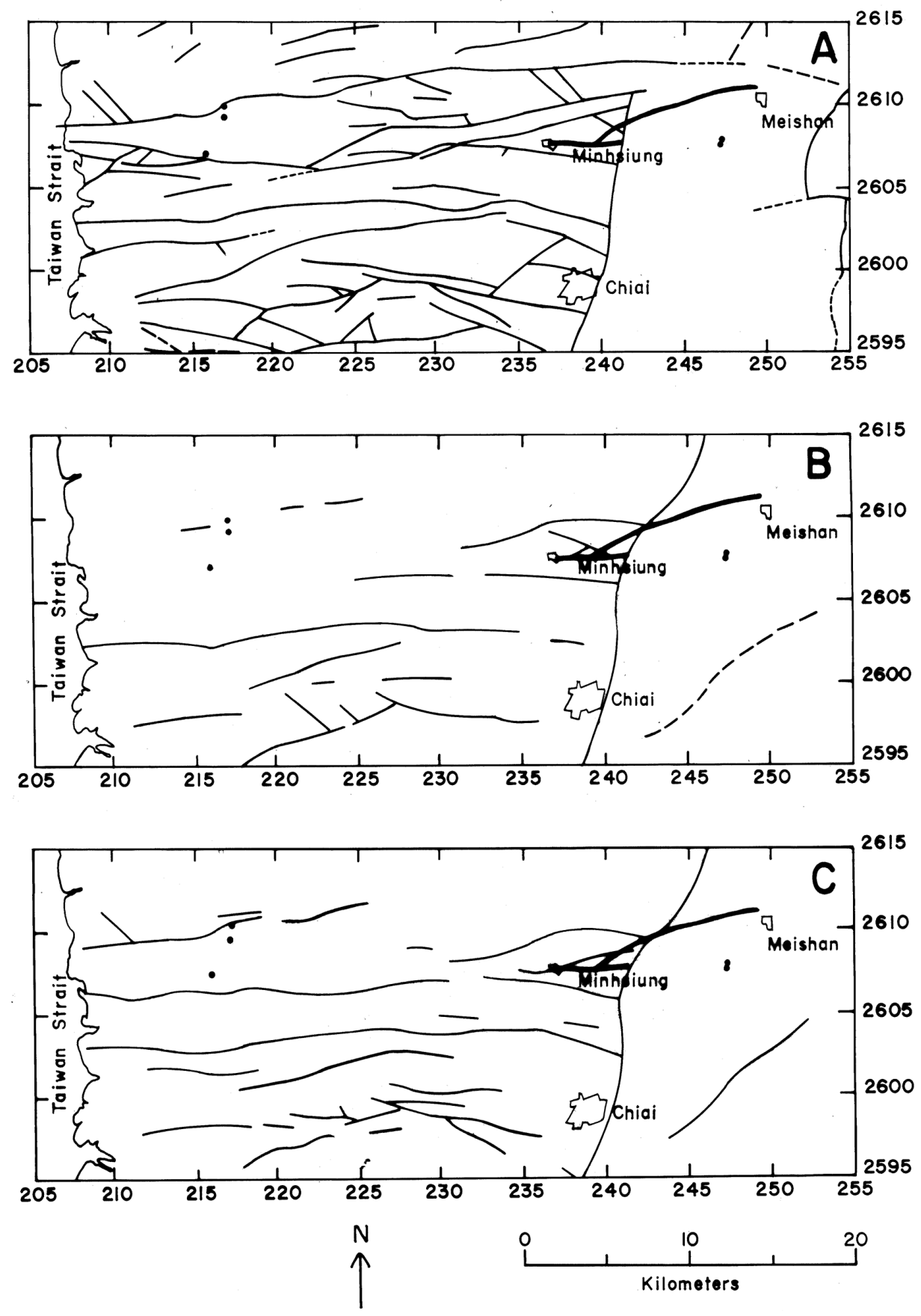

Figure 4. Faults identified by seismic surveys and drilling compared with the 1906 fault trace (heavy line). Wells shown by filled circle. Stratigraphic horizons cut by the faults are Middle Miocene (A), top of upper Pliocene (B), and base of upper Pliocene (C). Faults are from Meng (1961, fig. 3), Hsiao (1970, figs. 3 and 4), and Omori (1907, fig. 3). 


\section{The 1935 faulting}

Surface rupture occurred on two faults (no. 14 and no. 19, fig. 1) in northwestern Taiwan on 21 April 1935 accompanied by an earthquake that killed more than 3,000 people and destroyed more than 17,000 houses (Hsu, 1971, p. 158). The magnitude of the earthquake is given as 7.0 by Richter (1958, p. 582) and as 7.1 by Iida (1959, p. 100) and Hsu (1971, p. 158). The faults were called the Siko and Tonsikyaku faults in the Japanese reports (Earthquake Research Institute, 1936); the equivalent Chinese names are Chihhu and Tuntzuchio, respectively. The name Chihhu has also been applied to another fault in the vicinity (Tang, 1969). "Chihhu fault" as used in this report applies to the fault that ruptured in 1935.

Movement on the Chihhu or northern fault (C fig. 5; fig. 6, A), which trends about $\mathrm{N} 30^{\circ} \mathrm{E}$, was $15 \mathrm{~km}$ long, the northern $5 \mathrm{~km}$ of which consisted of short discontinuous ruptures (Otuka 1936, pl. 2 and p. 70). It dips $70^{\circ}-80^{\circ} \mathrm{W}$, and as the west side was uplifted $3 \mathrm{~m}$ relative to the east side (Otuka, 1936, p. 70) the faulting was of reverse type; however, a small right-slip component was noted in places (fig. 6, A). According to Iida (1959, p. 100) the strike-slip component was as much as $60 \mathrm{~cm}$. The maximum horizontal and vertical displacements did not occur at the same place judging from maps 6, 9, and 10 of the Earthquake Research Institute (1936).

The Tuntzuchio fault rupture (F. fig. 5; fig. 6, B) extended for approximately $12 \mathrm{~km}$, consisting of a series of en echelon ruptures of various lengths with right slip of as much as $1.5 \mathrm{~m}$ and vertical displacement of as much as $1 \mathrm{~m}$, with the northwest side generally downdropped except for about $1 \mathrm{~km}$ of its length at the northeast end, where the southeast side was relatively down (Otuka, 1936, p. 70). Judging from the published maps (Earthquake Research Institute, 1936, pl. 4 and maps 17 and 18) the maximum vertical displacement $(1 \mathrm{~m})$ reported by Otuka (1936, p. 70) did not occur at the same place as the maximum strike-slip (1.5 m). The displacements shown on figure 6 are from the maps published by the Earthquake Research Institute (1936) and differ somewhat from the numbers given in the summary report by Otuka.

In addition to the two faults described above, other ground ruptures occurred at many places in 1935. Some of these were clearly the result of landslides and related movements but others were probably subsidiary faults of tectonic origin. The latter are shown on figure 5 at A, B, D, and E. Some of these are discussed below.

A zone of probable secondary faulting (E, fig. 5) extended generally northward for 8 or 9 $\mathrm{km}$ from the vicinity of Mt. Kuantaoshan. The fractures constituting the zone are shown on plate 3 and maps 11, 12, 14, and 15 of the Earthquake Research Institute's 1936 report and are mentioned by Hayasaka (1935, p. 267). The maps show a series of disconnected but generally aligned fissures, each less than $1 \mathrm{~km}$ long. Although a few are indicated on the map as having some vertical displacement (down on east side), no measurements are given. The northern $6 \mathrm{~km}$ of this zone was along a stream valley and nontectonic streamward movement of sediments is a possible cause of the ruptures; however, the fissures were straight and did not follow the curved banks of the meandering stream nor the curved edges of the non-lateritic terrace deposits mapped in that area by Tang (1969). Analysis of triangulation data supports the interpretation that the fissures were tectonic, for it indicates that the fissures were near the edge of a zone of horizontal compression and along a zone of large divergence or dilation, although they did not have any simple relation to the pattern of vertical changes (Miyabe, Hukunaga and Sato, 1938, pt. 2, figs. 2, 6, and p. 590-591). At their most distant points, the fissures were about $6 \mathrm{~km}$ from a line connecting the Chihhu and Tuntzuchio faults. 


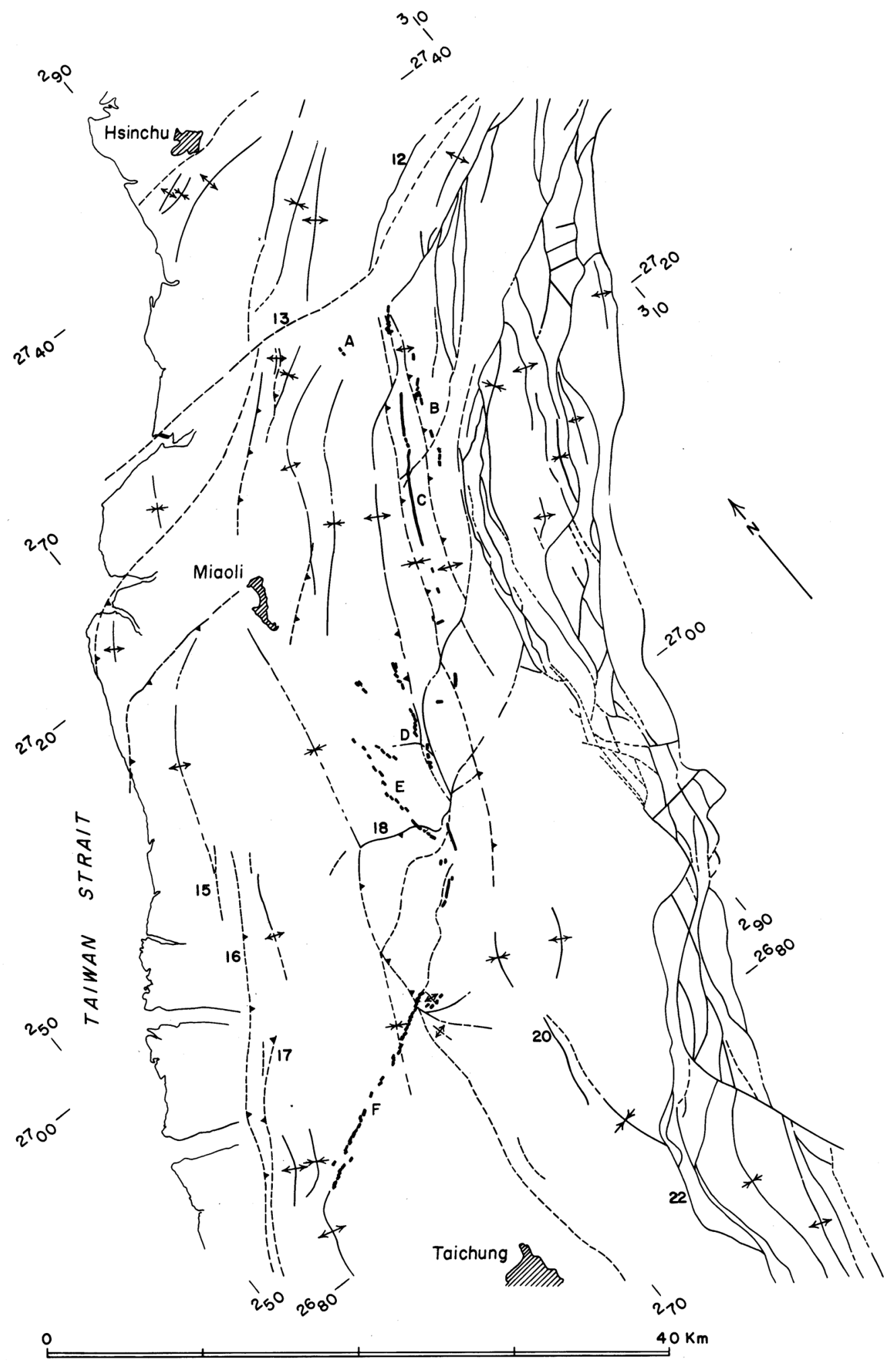

Figure 5. Map showing 1935 faults (heavy line) in relation to other faults and nearby anticlines and synclines. Localities discussed in text indicated by letters; numbered faults correspond with figure 1; converging pairs of arrows indicate synclinal axis; diverging pairs of arrows indicate anticlinal axis; barbs on upthrown side of reverse faults. The 1935 faults are selected from ground ruptures shown by Earthquake Research Institute (1936); other structures are from Tang (1969), Chinese Petroleum Corporation (1971), and Ku (1963). 

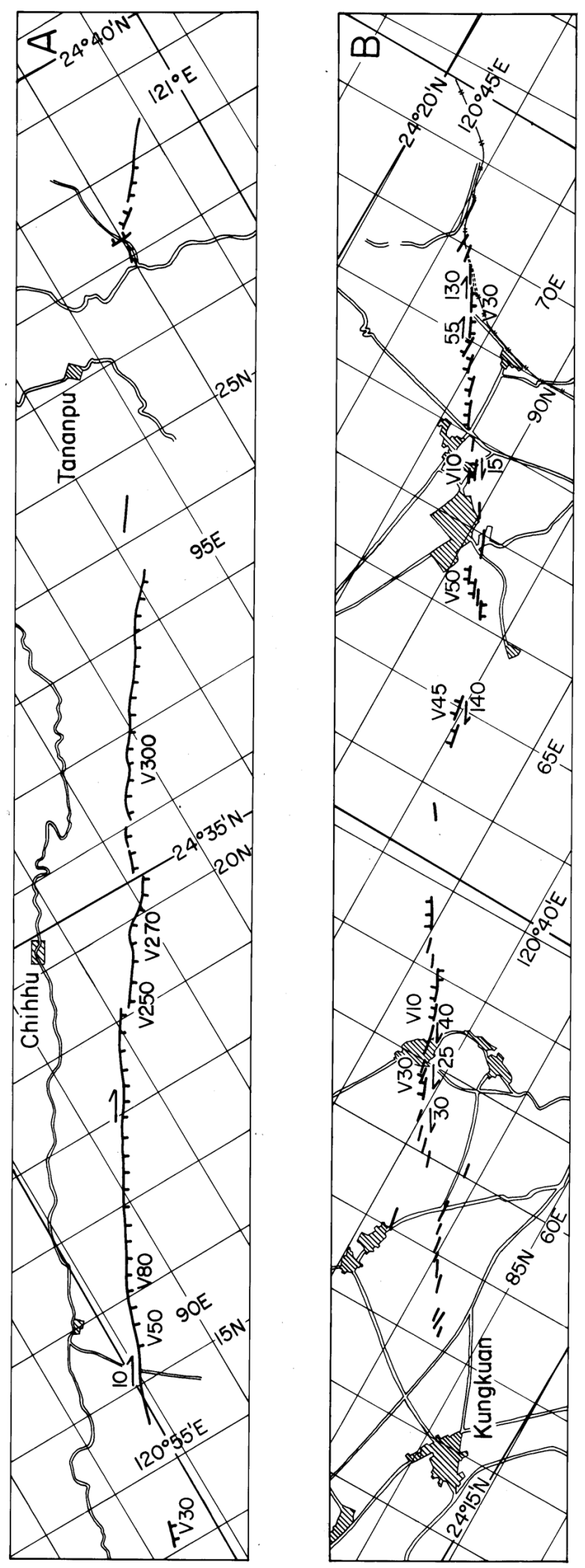

Figure 6. Maps showing 1935 Chihhu earthquake fault (A) and Tuntzuchio earthquake fault (B). Barbs on downthrown side of fault. Vertical displacement $(\mathrm{cm})$ indicated by $V$; horizontal displacement $(\mathrm{cm})$ indicated by arrow. Map grid has $1 \mathrm{~km}$ spacing. Slightly modified from Earthquake Research Institute (1936). 
A second zone of fissures occurred near Chuhuangkeng (Syukkwoko in Japanese), about half way between the zone described in the previous paragraph and a line joining the Chihhu and Tuntzuchio faults. This zone (D, fig. 5), which was at least $5 \mathrm{~km}$ long, also consisted of an alignment of discontinuous fissures. The fissures were along or close to ridge crests and some had vertical displacement of unspecified amount; the uphill side went relatively down on some and up on others (Earthquake Research Institute, 1936, map 12 and pl. 3). The zone trended north-northeast parallel to, and about $3 \mathrm{~km}$ west of, a line joining the Chihhu and Tuntzuchio faults. The fissures occurred in an area where triangulation showed net contraction, and leveling showed a general lowering of the land surface (Miyabe, Hukunaga, and Sato, 1938, fig. 2 and fig. 6).

A third zone of discontinuous fissures, 1 to $2 \mathrm{~km}$ east of the Chihhu fault and nearly parallel to it (B, fig. 5), extended at least $6 \mathrm{~km}$. The fissures were on the west side and near the crest of a long ridge, and the downhill (western) sides of the fissures were displaced downward (Earthquake Research Institute, 1936, p. 2, maps 6 and 10) about $0.5 \mathrm{~m}$ "in the total" (Hayasaka, 1935, p. 266). The fissures coincided with the physiographic expression of the east side of a graben according to the interpretation of Hayasaka (1935, p. 266) but later work (Tang, 1969; Chinese Petroleum Corporation, 1971) does not indicate a graben there. The anomalous $0.95 \mathrm{~m}$ eastward displacement of a triangulation station on the ridge (Miyabe, Hukunaga, and Sato, 1,938 , p. 590) together with the mapping of both landslide-type movements and earthquake fissures on the ridge (Earthquake Research Institute, 1936, pl. 2) suggests that some of the ground ruptures may have been of tectonic origin rather than the result of shaking.

The relation between the Chihhu and Tuntzuchio earthquake faults and nearby faults and folds is also shown on figure 5. Over most of its length the Chihhu earthquake fault parallels but lies more than $0.5 \mathrm{~km}$ from the Chihhu fault of Tang (1969); only about $1.5 \mathrm{~km}$ of its north end is approximately coincident with a mapped fault. Folds in the area consist of northeast-trending anticlines and synclines with axial reverse faults. From west to east they are the Chuhuangkeng anticline with a reverse fault dipping about $70^{\circ} \mathrm{W}$; the Chihhu syncline, slightly overturned toward the west and cut by a reverse fault dipping steeply east; and the Pakuali anticline, also overturned to the west and cut by a reverse fault dipping about $70^{\circ} \mathrm{E}$ (Chou, 1973, sec. C-D; Chinese Petroleum Corporation, 1971). The earthquake fault rupture occurred in the overturned beds that make up the east limb of the Chihhu syncline and the west limb of the Pakuali anticline. This structural position suggests the possibility that the faulting was merely a shallow-seated upward relief of stress in the tight syncline, particularly in view of the epicenter location more than $20 \mathrm{~km}$ south of the fault (Richter, 1958, p. 582, 584) and the report of two observers that the fault formed after the earthquake (Otuka, 1936, p. 70). Some doubt exists about the latter statement however, because another resident stated that the rupturing occurred at about the same time as the earthquake (Earthquake Research Institute, 1936, p. 174). The triangulation data suggest that the faulting was not just local, shallow stress-relief. Except for a few anomalous stations, the triangulation points showed a systematic regional pattern of displacement that extended at least $10 \mathrm{~km}$ west of the fault (Miyabe and others, 1938, figs. 1, 9), where the folds are gentle.

Descriptions of the Chihhu fault (Earthquake Research Institute, 1936) coupled with the position of the rupture when transferred to the photogeologic map of Tang (1969) indicate that it broke the surface at the outcrop, and probably near the base, of the Miocene Kuantaoshan 
sandstone. Apparently it was not a bedding plane fault, because it dipped $70^{\circ}-80^{\circ} \mathrm{W}$ (Otuka, 1936, p. 70) and, according to the information at hand, the beds dip eastward. The rupture cut across the lower parts of a series of spurs that form the flank of a long, dissected ridge.

Longitudinal profiles of the spurs (Otuka, 1936, fig. 3) show high points that in effect form a discontinuous small ridge on the lower slopes of the main ridge. The rupture was on the uphill side of the small ridge, which may be a fault scarp as suggested by Kaneko (1970, p. 220). However, the ridge may be partly or wholly the result of differential erosion, as it parallels the strike of the beds and coincides with the outcrop of a resistant sandstone (presumably the Kuantaoshan sandstone) at the base of Unit 4 of Tang (1969). The same sandstone has formed other prominent ridges in the vicinity, one in an analogous topographic position on the west flank of the Chuhuangkeng anticline north of the Hou Lung River (Tang, 1969, fig. 1). Thus the relief of the small ridge that the 1935 fault followed may or may not be the result of pre-1935 faulting. In places the 1935 Chihhu rupture showed a small right-slip component, and Kaneko (1970, p. 220) reports possible suggestive evidence of this sense of movement. The finely detailed photogeologic map of Tang permits assessment of prehistoric strike-slip movements on the fault. Of 32 small streams that cross the zone that ruptured in 1935, 69 percent cross with no change, 25 percent curve left, and 6 percent curve right. Although this suggests that prehistoric strike-slip has been predominantly left- handed, none of the stream deflections are convincingly the sole result of strike-slip displacement. The deflections could all result from the erosion resistance of the sandstone, perhaps coupled with prehistoric vertical displacements.

Information at hand indicates that landforms do not reveal the Tuntzuchio fault (fig. 5, F; fig. 6, B) in the coastal plain where 98 percent of its length lies. Conditions are not ideal for surface observations as the area is primarily used for growing sugar cane and rice. The fault is in line with a fault in the hills and its southwest end does coincide with an anticline (fig. 5), but these relations are not strongly indicative of a fault in the coastal plain and none is shown on modern geologic maps made for petroleum exploration. The maps of Tang (1969, fig. 1) and Chang (1971, fig. 1), both at 1:100,000 scale, together cover the area where the Tuntzuchio fault broke the surface in 1935. The maps show mostly Pleistocene lateritic terrace deposits in the coastal plain. No difference in terrace deposits related to the fault are shown on the maps, and a terrace scarp crosses the fault obliquely with no apparent offset at a place where $1.4 \mathrm{~m}$ of right slip occurred in 1935. The rupture was more or less coincident with a small stream for about $2.5 \mathrm{~km}$ near Houli and was on the crest of a ridge northeast of Kungkuan but otherwise showed no systematic relation to landforms. However, recent field investigations by Yao (1974, personal communication) indicate that sandstone of the Kuantaoshan formation is folded and otherwise disturbed by faulting along the Tachia River (near F, fig. 5). The 1935 rupture crossed the Sani-Chelungpu reverse fault northeast of Houli at a $55^{\circ}$ angle and for $0.9 \mathrm{~km}$ coincided with an unnamed northeast trending fault shown by Tang (1969). On the unnamed fault Tang shows a fault scarp in, and possible right-lateral displacement of, a Pleistocene lateritic terrace north of the Taan River. This is the same sense of strike- slip displacement as occurred in 1935. The southwest end of the Tuntzuchio fault is essentially coincident with a $2 \mathrm{~km}$ segment of the axis of the gently-folded Tatushan anticline where the latter has a $\mathrm{N} 60^{\circ} \mathrm{E}$ trend on the map of Chang (1971, fig. 1). Most of the fault generally parallels the structural contours on the top of the Chinshui Shale of Pliocene age as determined by seismic investigations (Chang, 1971, fig. 4). 


\section{The Hsinhua fault, 5 December 1946}

The 1946 faulting occurred in the coastal plain and foothills in the southwestern part of Taiwan about $10 \mathrm{~km}$ northeast of Tainan (no. 30, fig. 1; fig. 7). The associated earthquake of magnitude 6.3 (Hsu, 1971, p. 159) killed 74 persons and destroyed 3,577 houses (Chang and others, 1947). The surface break extended at least $6 \mathrm{~km}$ with a trend of $\mathrm{N} 70^{\circ}-80^{\circ} \mathrm{E}$ and showed consistent right slip, with the southeast side relatively down where it had a clearly defined trace. The maximum right slip $(200 \mathrm{~cm})$ and maximum dip slip $(76 \mathrm{~cm})$ components occurred at the same place, yielding an oblique slip of $214 \mathrm{~cm}$. The total length of the fault in the subsurface probably was $12 \mathrm{~km}$ or more, because groups of en echelon cracks and warps with small vertical displacements were found in a linear zone extending about $6 \mathrm{~km}$ southwest of the surface fault (F, fig. 7). The en echelon cracks generally trended northwest and right slip (as much as $15 \mathrm{~cm}$ ) was measured on a few of them. The vertical displacements that were reported indicated that the north side of the probable subsurface extension may have been lowered, in contrast to the surface fault to the east along which the south side was lowered.

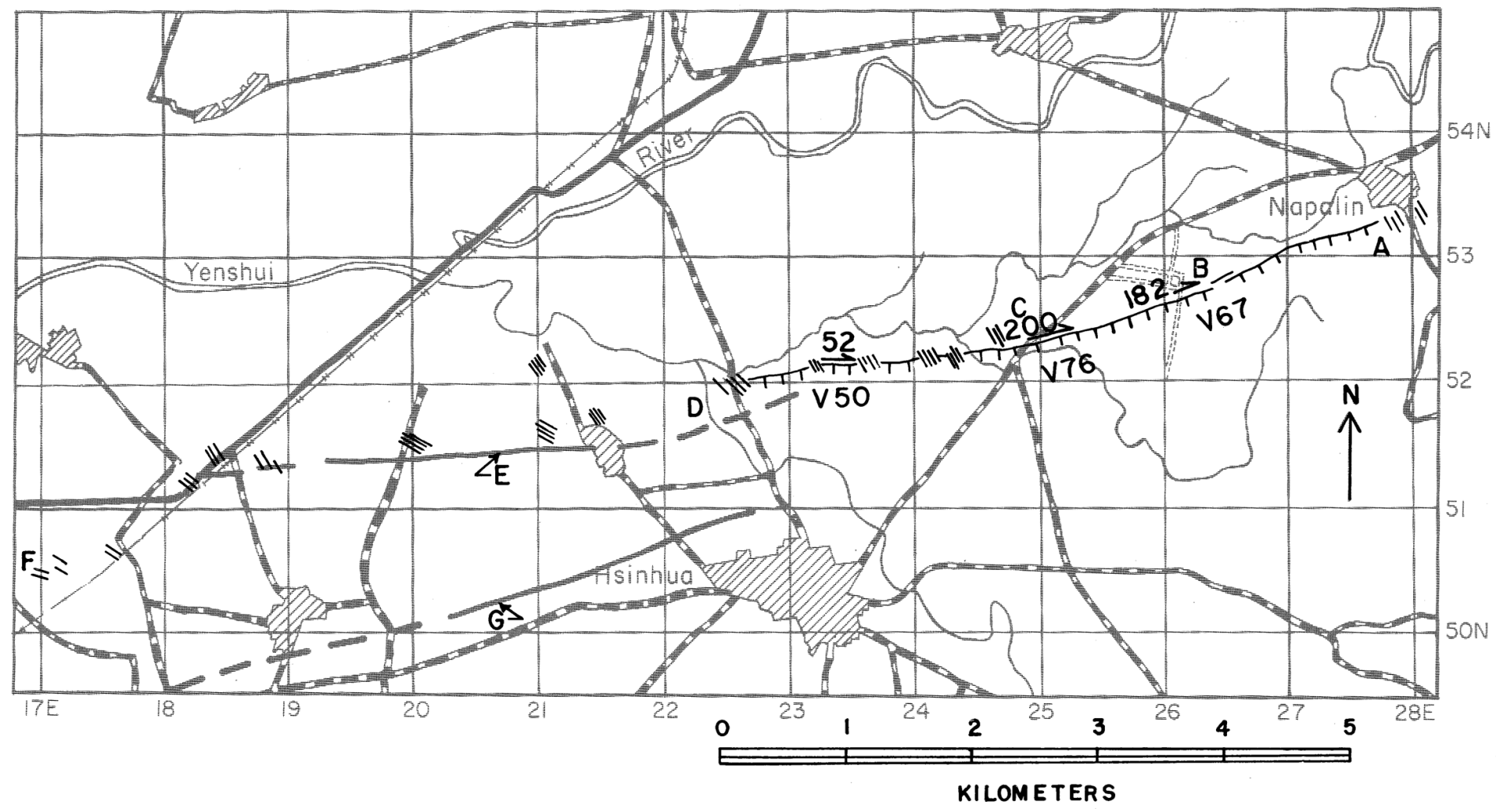

Figure 7. Map showing 1946 fault trace, after Chang, Chow, and Chen (1947). Displacements given in centimeters; V indicates vertical displacements; barbs on downthrown side. Faults E and G shown on screened base are from Sun (1964, pl. 3).

Neither the Chinese Petroleum Corporation (1971) geologic map nor the photogeologic map of Sun (1964) shows a fault where the 1946 rupture occurred. Most of the fault was in rather flat land devoted to farming and the rest of it was in low rolling hills with few exposures of the subsurface materials. The writer accompanied by T. H. Yao and H. P. Lueng looked at the place where the maximum displacements occurred in 1946 (C, fig. 7) but could find no clear 
evidence of the faulting there or in the vicinity of point B (fig. 7). Evidence suggestive of creep near point $\mathrm{B}$ is described in a following section of this report. In a friable sandstone at A we found numerous steep fractures striking $\mathrm{N} 80^{\circ} \mathrm{E}$, approximately parallel to the 1946 rupture. Just west of point A the fault passed through a topographic saddle, but east of point B it passed near the summit of a hill. No clear fault topography was seen on the ground and the writer did not have access to aerial photographs of this area to look for other surface evidence of faulting.

A structural contour map based on seismic surveys was prepared by Y. S. Pan in 1961 and published by Sun (1964). The map shows two faults at a depth of about 1,500 m, northwest of Hsinhua which are shown at E and G, figure 7. Fault E practically coincides with the subsurface extension of the 1946 fault indicated by the en echelon fractures between D and F. Although the vertical separation on the fault is not shown on the map one can assume that in order to have been detected by the seismic survey it must have been substantially greater than the 1946 vertical component $(0.76 \mathrm{~m})$ and therefore the fault had moved prior to 1946 . The structural horizon shown on the map as displaced by the fault is the Gutingkeng formation, which is uppermost Pliocene in age (Chou, 1973, table 1), and thus the fault had post-Pliocene movement prior to 1946.

\section{The Longitudinal-Valley faulting, 1951}

Two surface ruptures occurred in the Longitudinal Valley of eastern Taiwan in 1951. The first of these occurred on the Meilun fault near Hualien on October 22 (Hsu, 1962a) associated with an earthquake of magnitude 7.1 (Hsu, 1971, p. 159) which killed 45 persons and destroyed 522 houses (Cheng, 1960, p. 399). The location of the fault is shown on figure 1 (no. 43) and figure 8. Its position is well fixed just south of the shoreline where it followed a scarp about $20 \mathrm{~m}$ high that is conspicuous on the ground as well as on the aerial photograph published by Hsu (1962a, pl. 1). South of the well-defined scarp the fault is assumed to lie near the western base of the hill Milunshan, just north of the main part of Hualien, where fissures occurred in 1951. The faulting may have extended into Hualien itself, where northwest trending fissures mentioned by Hsu,(1955, p. 154) and Cheng (1960, p. 399) had the proper orientation for en echelon fractures produced by left slip, but its location is uncertain. Possibly the fault curved eastward near its south end to produce the subsidence of $100 \mathrm{~cm}$ at the southern sea beach reported by Cheng (1960, p. 399) but local ground failure caused by shaking is a more plausible explanation of the subsidence. The length of faulting is given variously as 5 to $7 \mathrm{~km}$ (Hsu, 1962a, p. 96; 1955, p. 159) which can be taken as a minimum, inasmuch as the fault extended beneath the sea at the north end.

Maximum reported displacements in the October 22 faulting were $2 \mathrm{~m}$ of left slip and 1.2 $\mathrm{m}$ uplift of the southeast side of the fault (Hsu, 1955, p. 159; 1962a). The location at which the strike-slip measurement was made is uncertain but the vertical displacement was measured at the north end of the landward part of the fault at the village of Chihsingtan, according to the caption of a photograph published by the Taiwan Weather Bureau (no date). T.H. Yao and the writer briefly examined this locality in January 1973. The vertical displacement was evident as a northwest-facing scarp but we saw no obvious evidence of strike-slip displacement. Assuming that the reported maximum horizontal and vertical components of displacement occurred at the same place the calculated left oblique slip is $2.3 \mathrm{~m}$. Hsu (1962a, p. 101) and Biq (1971, p. 21) believed that both the October and November 1951 faulting included a thrust component, 


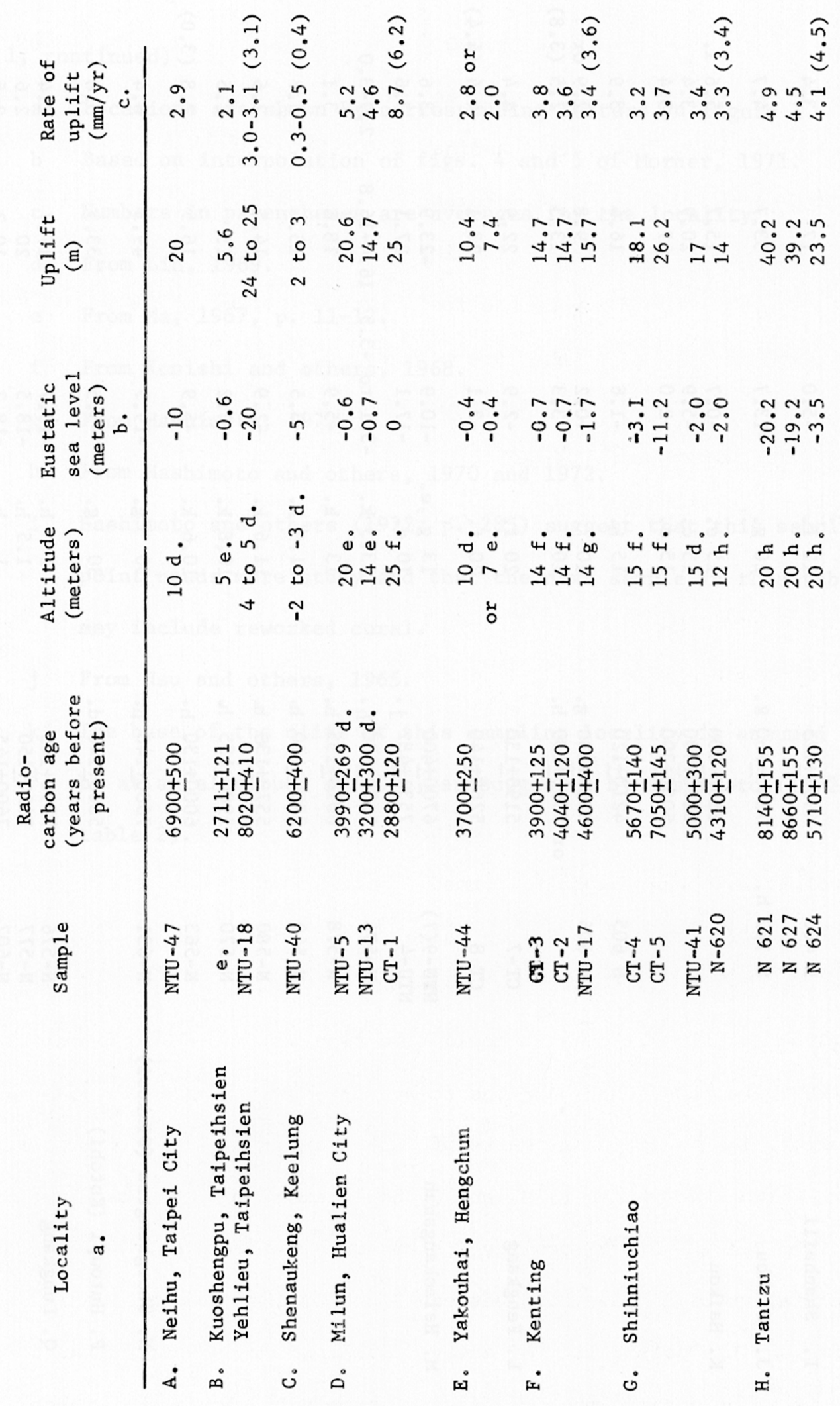

Table 1. Approximate long-term minimum uplift rates 


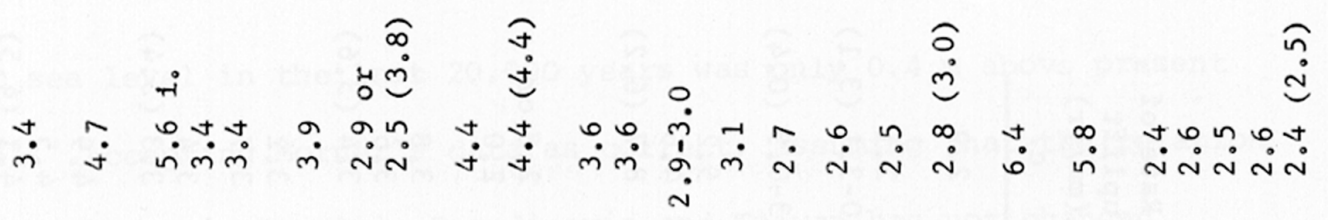

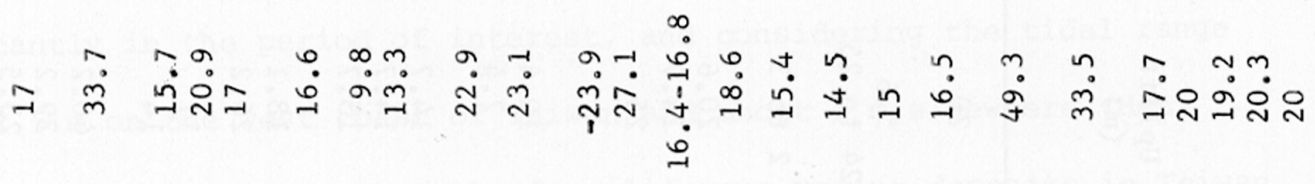

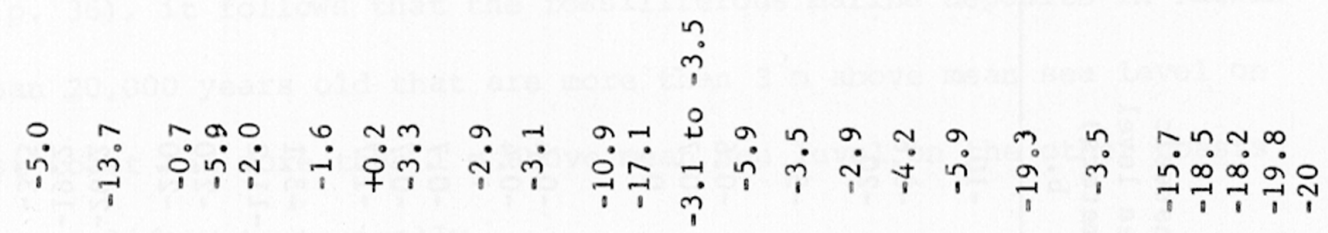

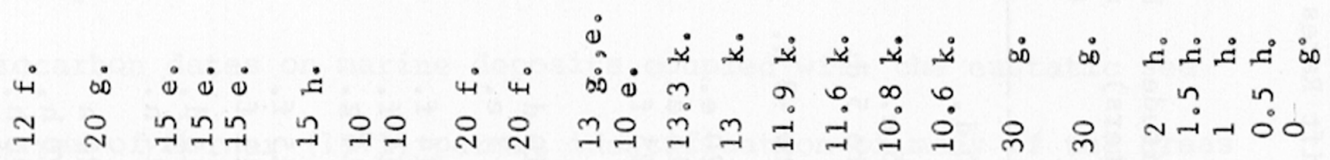

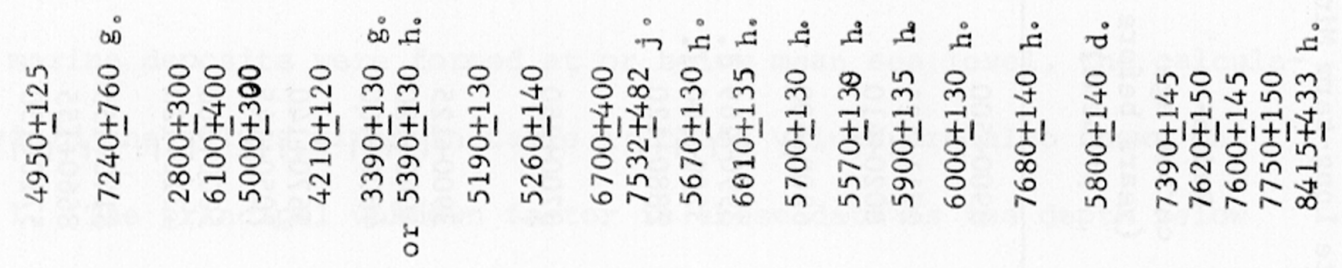

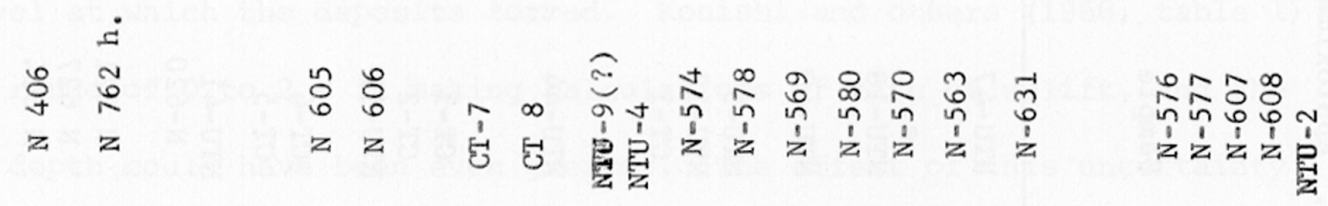
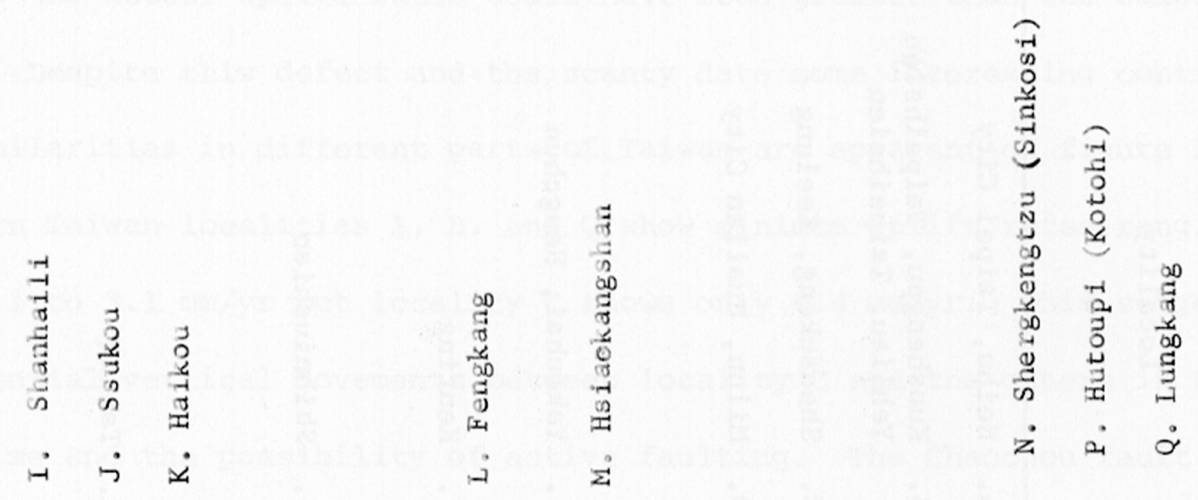

Table 1, continued 
Notes: a Locations are shown by corresponding letters on figure 1.

b $\quad$ Based on interpolation of figs. 4 and 5 of Morner, 1971.

c Numbers in parentheses are averages for the locality.

d From Lin, 1969.

e From Ma, 1967, p. 11-12.

f From Konishi and others, 1968.

g From Hashimoto, 1972.

h From Hashimoto and others, 1970 and 1972.

i Hashimoto and others (1972, p. 285) suggest that this sampling point needs more study and that the next sample in this table may include reworked coral.

j From Hsu and others, 1965.

$\mathrm{k} \quad$ The base of the cliff at this sampling locality is assumed to be at an altitude of 10 m, as suggested by Hashimoto (1972, table 2).

although the direction of dip of the fault was difficult to determine in the recent sediments (Biq, 1970, personal communication). First-motion studies of several earthquakes (Hsu, 1971, fig. 29) tend to support this interpretation. Thus the October 22 faulting is classed as left reverse oblique slip.

Subsidiary faulting may have occurred near the west edge of the Longitudinal Valley about $5 \mathrm{~km}$ from the main fault on October 22. The undated report by the Taiwan Weather Bureau has two photographs showing fresh scarps with uplift of 1.5 and $2.1 \mathrm{~m}$ respectively at Fuhsingtsun. Presumably this locality is the same as a town of that name shown on the $1 / 50,000$ scale topographic map $5 \mathrm{~km}$ west-southwest of the center of Hualien, near the western edge of the Longitudinal Valley. Another photograph in the Weather Bureau report shows an open fracture $0.5 \mathrm{~m}$ wide on the mountain slope near the town, which suggests that landsliding may account for the uplift; however, the center of Fuhsingtun is $0.8 \mathrm{~km}$ from the base of the mountains and the town is not among the places listed in the tabulation of localities where landslides and avalanches occurred (Taiwan Weather Bureau undated report, p. 11). Although inconclusive, the data at hand suggest that subsidiary faulting produced the scarps at Fuhsingtsun.

The October 22, 1951 faulting occurred along a pre-1951 scarp that was nearly $20 \mathrm{~m}$ high and that forms the straight edge of an area of Holocene marine deposits that have been uplifted as much as $46 \mathrm{~m}$ (Lin, 1969). Ponds at the foot of the scarp are probably fault-related sag ponds (Hsu, 1962, p. 96). Thus the evidence strongly indicates that the 1951 movement was the reactivation of an older fault. Radiocarbon dating of elevated marine deposits in the vicinity yields a surprisingly high average annual rate of uplift that ranges from 4.6 to $8.7 \mathrm{~mm} / \mathrm{yr}$. (see table 1); presumably the uplift has occurred as a series of sudden displacements similar to the 1951 increment.

The second surface rupture in the Longitudinal Valley in 1951 occurred on November 25 associated with an earthquake of magnitude 7.3 (Allen, 1962, p. 4808) that caused 20 deaths, injured 326, and destroyed more than 1,000 homes (Hsu, 1971, p. 159). The approximate location of the surface faulting, which was discontinuous, is shown on figure 1 (no. 42) and figure 8, somewhat modified from Hsu (1962, fig. 1). The fault has been closely located in Yuli (see the section on tectonic creep in this report) and T. H. Yao and the writer were shown the approximate position of the fault near the west edge of the village of Wulou $(3.8 \mathrm{~km}$ north of Juisui, which is 


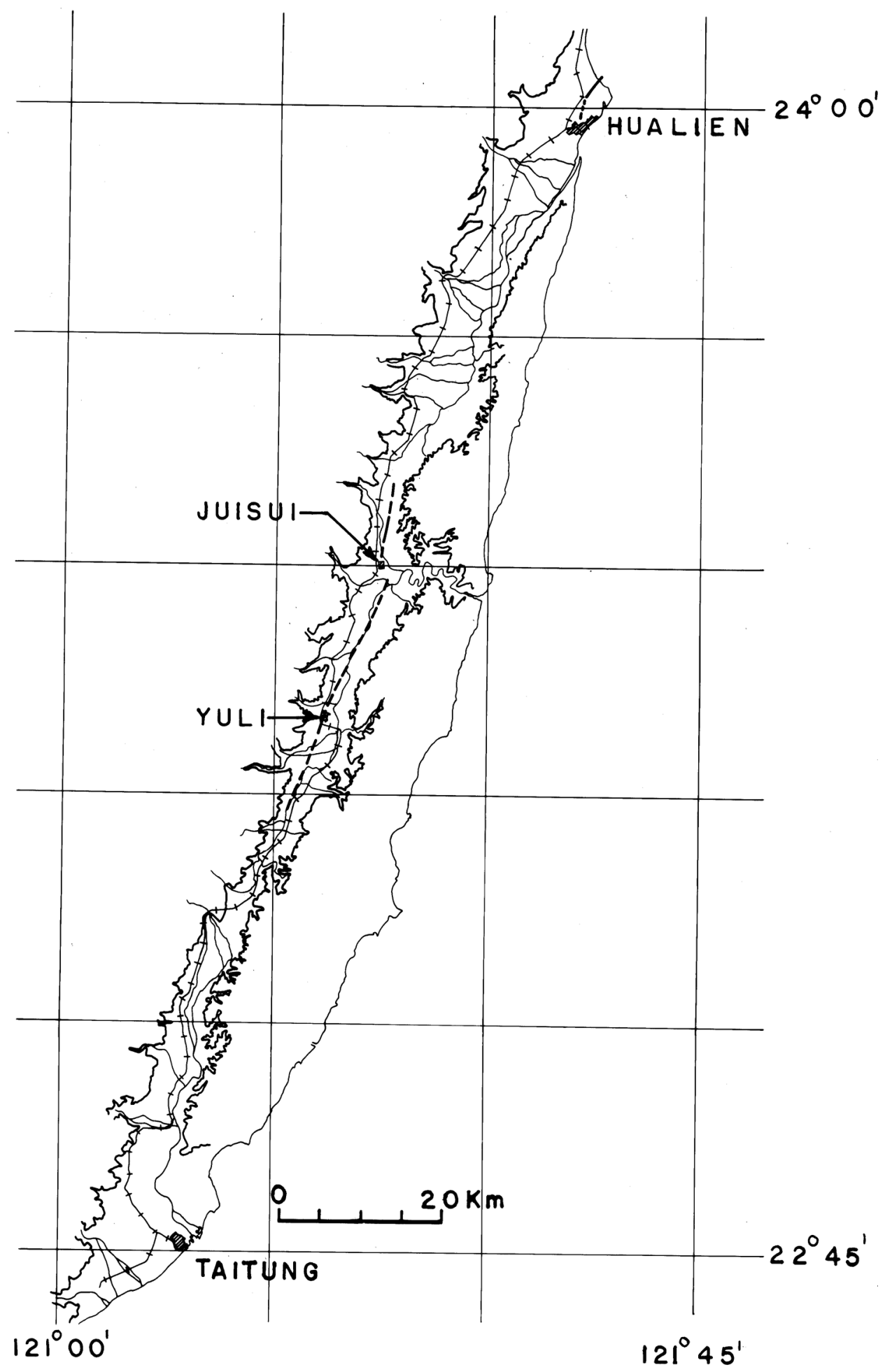

Figure 8. Map showing 1951 faulting (heaviest line), modified from Hsu (1962), Longitudinal Valley as outlined by 300-meter contour (intermediate weight line), principal streams, and railroads.

also called Shuishui) by some of the residents. On figure 8 the fault has been drawn so as to pass through the point located in Wulou, somewhat westward of the position shown on Hsu's map. The resulting en echelon pattern seems quite reasonable because examination on figure 8 will 
show that the Longitudinal Valley itself has en echelon arrangement, the centerline of the segment north of Juisui lying some $5 \mathrm{~km}$ northwesterly of the centerline south of Juisui. The Wuhao (also called Saopa) terrace of Pleistocene age (Ku, 1964, pl. 1) lies just southwest of Juisui. The writer saw no convincing topographic evidence of young faulting in the northeastern two-thirds of this highland, either on aerial photos that were briefly examined or on a 1/10,000 scale soil map with a 5- meter contour interval, and therefore the fault is drawn just southeast of the edge of the highland. From there south the position of the fault line is inferred as far as the known location at the Yuli Primary School in Yuli. South of the school, the fault is drawn to pass through the pond and fountain in the circle in Yuli, which according to a long-time resident, Mr. C. Y. Huang, was originally a natural spring. Mr. T. H. Yao and the writer were shown another spring and a formerly swampy area that has been deepened to form a pond, $0.6 \mathrm{~km}$ and $0.8 \mathrm{~km}$ respectively south-southwest of the circle. A farmer, living $3.8 \mathrm{~km} \mathrm{~S} 19^{\circ} \mathrm{W}$ of the circle in Yuli, said that cracks formed in his yard and nearby fields during the 1951 earthquake. The buildings and other structures there have all been built since 1951 so no evidence of the rupture remains, but he impressed Mr. Yao and the writer as a credible witness, and the fault is shown as a solid line on figure 8 from the Yuli School southward to that point.

The maximum displacements reported for the November 25, 1951 faulting were $1.63 \mathrm{~m}$ left slip and $1.3 \mathrm{~m}$ of vertical displacement, up on the east. These were both measured at the same place northeast of Juisui (Hsu, 1962a, pl. 2) and yield a left oblique slip of $2.08 \mathrm{~m}$. At the Yuli School the maximum left slip apparently was only about $40 \mathrm{~cm}$ (see section on tectonic creep) with essentially no vertical component, but the prehistoric Chihshang fault (no. 41, fig. 1), south of and in line with the 1951 rupture, has had a strong vertical component of movement with the east side up (Hsu, 1962a). Because of this and the reasons discussed above in connection with the October 22 faulting, the November 25 faulting is believed to have had a reverse component and is also classed as left reverse oblique slip.

Evidence for prehistoric but geologically young faulting can be seen at a few places near the November 25 line of rupture. Quaternary scarps of at least two ages occur east of Fuyuan, about $8 \mathrm{~km}$ north of Juisui (Allen, 1962, p. 4806); young gravel deposits just south of Juisui are steeply inclined, probably as the result of faulting (Hsu, 1962a, p. 98); and the Chihshang fault, which has a straight scarp and sag pond of probable Holocene age, is in line with and south of the 1951 fault (Hsu, 1962a, p. 98; Allen, 1962, p . 4806).

\section{Faults That Cut Holocene or Pleistocene Deposits}

Figure 1 shows faults that displace Holocene or Pleistocene deposits according to the literature available to the writer. Although a complete search was not made, the majority of the English-language reports are believed to have been included. Some of the faults shown on figure 1 may be covered by unfaulted deposits which prove them to be inactive; however, on the basis of the published literature and the criteria listed in a preceding section of this report, they may be active and therefore their significance needs to be considered in planning for important structures. Any of the many faults in Taiwan that at the surface are entirely in pre-Pleistocene rocks could of course have moved in Pleistocene or Holocene time without leaving any stratigraphic record of their movement, but the faults discussed below and shown on figure 1 at least provide a starting point for studies of active faults. The evidence concerning each fault is mentioned and the source of the information is given so that the interested reader can obtain more details. 
The Wuku, Tananwan, and Nankan faults of Ku (1963), not shown-on the geologic maps by Tang (1964) and by Ho 1,1969), are numbered 1,2, and 3 respectively on figure 1 . The Wuku fault has a 'low straight scarp and the Tananwan fault has well developed triangular facets according to $\mathrm{Ku}$ (1963, p. 53). The 100-150 m difference in height of Pleistocene terraces (Ho, 1969 , p. 72) plus the straightness of the scarp (Ku, 1963, p. 53) are the basis for inferring the Nankan fault. $\mathrm{Ku}$ indicates a fault scarp along each of the faults but his map does not show the type and age of materials composing the scarps. In the vicinity of the scarps, Tang shows lower Pleistocene Hsiangshan facies of the Toukoshan formation and Holocene alluvium, and Ho shows Tananwan formation or Linkou formation, both Pleistocene, and Holocene alluvium. Thus these faults, if they exist, cut deposits at least as young as Pleistocene. Ku also shows a fault scarp along the Shanchiao fault on the west side of the Taipei basin. His map shows a patch of Pleistocene terrace athwart, and apparently not cut by, the fault and therefore the fault is not shown on figure 1. It may however, warrant further investigation.

The Tsaota fault (no. 4) is described by Ku (1963, p. 54) as having a scarp 5 to $6 \mathrm{~m}$ high in sand dunes and he infers the movement to be very recent. The Chinese Petroleum Corporation (1971) geologic map indicates that the dune sand is of Holocene age; hence the fault has probably moved in Holocene time.

The group of east-northeast striking faults (5, 6, 7, and 8, fig. 1) that cut Pleistocene terraces were named the Yangmei faults by $\mathrm{Ku}(1963$, p. 53). All but number 7 are downdropped on the north side. The southernmost and longest (no. 8) of this group of faults has offset the boundary between two Pleistocene terraces right laterally a small amount in addition to having a scarp $30 \mathrm{~m}$ high $(\mathrm{Ku}, 1963$, p. 53-54, pl. 1). In a cross section Tang (1964, fig. 13) labels this the Hukou fault and indicates a reverse component of displacement on it. Tang's section crosses faults 6,7 , and 8 and passes just west of fault 4 of figure 1, but shows no faults at these points.

The short north-trending fault (no. 9) was shown with a question mark on the map by $\mathrm{Ku}$ (1963, pl. 1). Ku's map does not clearly indicate whether he intended to represent the fault as displacing the Pleistocene terrace deposit but Tang's map (which does not show a fault there) shows Pleistocene deposits entirely surrounding the position of the fault. The location of the fault is indicated on figure 1 even though its existence and age are uncertain.

The group of faults southeast of Hsinchu are from the publications of Tang (1964 and 1968). The Hsincheng fault (no. 10, fig. 1) has a north-facing scarp as much as $60 \mathrm{~m}$ high just west of the Touchien River which not only truncates Pleistocene lateritic terraces but also the non-lateritic terraces. The youngest of these terraces is considered Holocene by Tang (1968, p. 78). The scarp in this vicinity is conspicuous in the field but has been terraced and otherwise modified for farming. Fault number 11 on figure 1 is shown on the map by Tang $(1964$, pl. 1) as cutting the lower facies of the Toukoshan formation (shown on Pleistocene on Tang's map) and possibly a Pleistocene terrace deposit southeast of Kuanhsi. The Chutung fault (no. 12, fig. 1) apparently cuts the Pleistocene Huoyenshan facies of the Toukoshan formation and possibly one of the non-lateritic terraces but the relations are unclear on the map (Tang, 1968, pl. 1). The Touhuanping fault (no. 13, fig. 1) has a small north-facing scarp 2-3 $\mathrm{m}$ high that is clearly visible on aerial photos and at some places on the ground. Tang $(1968$, p. 78$)$ reports that movement has occurred since the formation of a Holocene terrace. Evidence of tectonic creep was sought but not found at two places where the fault was examined (see section on fault creep). 
The Chihhu fault movement of 1935 (no. 14, fig. 1) has been discussed in the section on historically active faults.

Both Ku (1963) and Tang (1969) show a southeast-facing fault scarp east of Yuanli (no. 15, fig. 1) that developed in Pleistocene terrace deposits and lies on the axis of an anticline; $\mathrm{Ku}$ (1963, pl. 55) gives the scarp height as 20 to 30m. About $1 \mathrm{~km}$ east of that fault Tang shows a parallel but northwest-facing scarp also in Pleistocene terrace deposits. Tang suggests that the eastern fault extends southwestward under the alluvium of the Taan River to join the Changhua or Tachia fault (no. 16, fig. 1). The sense of displacement on this fault is uncertain. Both Tang and $\mathrm{Ku}$ show various terrace deposits including non-lateritic ones, bounded on the west by the Changhua fault just east of Tachia, $23 \mathrm{~km}$ north of Taichung. This indicates uplift of the southeast side of the fault at that place; however, Chang (1971, p. 27, 39) reports, on the basis of a drill hole and seismic surveys, that the fault is downthrown on the southeast near Changhua, $16 \mathrm{~km}$ west-southwest of Taichung. The Chinese Petroleum Corporation (1971) map shows the entire length of this fault with a dashed line, which symbolizes a concealed or inferred fault.

Two southeast-facing scarps just east of Tachia cut the non-lateritic as well as older terraces (Tang, 1969, fig. 1). The more easterly of this pair (no. 17, fig. 1), called the Tiehchenshan fault by Tang, approaches the Changhua fault southwest of Tachia. This seems to be the same fault that Sun (1965, p. 165) describes as a thrust that has produced a stratigraphic displacement of $20 \mathrm{~m}$ of the laterite.

The Sani fault (no. 18, fig. 1) cuts the Pleistocene upper Toukoshan formation near the west end of its east-west portion (Meng, 1963; Tang, 1969, fig. 1). About $13 \mathrm{~km}$ east of that point, where the fault is interpreted as a right-slip fault, Tang's map shows a fault scarp in Miocene-Pliocene formations. An earthquake with magnitude between 2 and 3 occurred on or close to the Sani fault in 1973 (Hsiung and Lo, 1973b). Turning southward, the Sani fault joins or becomes the Chelungpu thrust fault (no. 21, fig. 1) which, although the trace is covered by alluvium, is inferred on the basis of indirect evidence to cut the Pleistocene Toukoshan formation (Chang, 1971, p. 23-24 and fig. 7; Chou, 1973, section E-F). Ku (1963, pl. 2) has indicated questionable fault scarps at three places along this fault within $18 \mathrm{~km}$ of Taichung.

The Tuntzuchio fault rupture of 1935 (no. 19, fig. 1) has been discussed in the section on historically active faults.

Two east-facing scarps (no. 20, fig. 1) 3 to $5 \mathrm{~km}$ east of the Chelungpu fault cut Pleistocene terrace deposits according to $\mathrm{Ku}(1963, \mathrm{pl}$. 2). The northern scarp apparently does not cut the non-lateritic terraces that border the Tachia River.

The Tamaopu-Shuangtung fault (no. 22, fig. 1) cuts the Huoyenshan (lower Pleistocene) facies of the Toukoshan formation (Chang, 1971, fig. 1). The Chinese Petroleum Corporation (1971) map shows the fault also cutting upper Pleistocene terrace deposits, but this may not have been intentional. The fault is a reverse fault, upthrown on the east (Ho, 1959, p. 71), with a measured dip of $55^{\circ} \mathrm{E}$. at one excellent outcrop of the fault (Chiu, 1972, fig. 6). The geologic map by Chiu (1972, fig. 3) shows a northeast-trending fault that cuts the Shuangtung fault but apparently does not cut the upper Pleistocene terrace deposits. The epicenter of a 1973 earthquake in the magnitude range 2 to 3 was on or near the Shuangtung fault according to a map of Hsiung and Lo (1973a, fig. 4). 
The Shuilikeng-Tatakou fault (no. 23, fig. 1) is shown on the Chinese Petroleum Corporation (1971) map with a solid line, and therefore apparently cutting the upper Pleistocene terrace deposits at points $19 \mathrm{~km}$ north of and just south of Shuilikeng. At terrace deposits of the same age $27 \mathrm{~km}$ north of and $3.5 \mathrm{~km}$ and $9 \mathrm{~km}$ and south of Shuilikeng, however, the fault is shown with a dashed line, which represents a concealed or inferred fault.

A short unnamed northwest-trending fault (no. 24, fig. 1) cuts Pleistocene deposits east of Kukeng according to the Chinese Petroleum Corporation (1971) map.

The Tachienshan fault (no. 25, fig. 1) marks the contact between Tertiary and Pleistocene formations along most of its length and may cut non-lateritic terrace deposits northeast of Chushan, $41 \mathrm{~km}$ northeast of Chiai (Chinese Petroleum Corporation, 1971). It joins the Chukou fault (no. 29) on the south and probably joins the Chelungpu fault on the north.

Fault number 26 is the 1906 rupture and has been discussed in the section on historically active faults.

A fault that cuts Pleistocene formations is shown extending to the ground surface in two published cross sections (Sun, 1965, pl. 3; Meng, 1967, fig. 5). Sun labels it fault "A" and Meng refers to it as the Yichu fault. The general location of the Yichu fault as shown in the published sections is indicated by no. 27 on figure 1. There the fault has an east-west trend and the sections show greater formational thicknesses on the south side of the fault than on the north side. In view of historic strike-slip faulting to the northeast (no. 26 fig. 1) and southeast (no. 30, fig. 1) one suspects that at least part of the differences in formation thickness is the result of a strike-slip component of displacement on the fault. Although his photogeologic study revealed no surface evidence of the fault, Sun (1971, p. 70) suggests that it may extend eastward to join his inferred Chutzuchiao fault. The Yichu fault is not shown on the photogeologic map of Sun (1971) nor the geologic map of the Chinese Petroleum Corporation (1971).

The Muchiliao fault (no. 28, fig. 1) is shown on two maps by Sun $(1970,1971)$ who reports that the latest activity on the fault followed deposition of lagoon and marsh deposits which he places in the Holocene (Sun, 1971, p. 66, 70). The fault is expressed as a somewhat eroded scarp some $7 \mathrm{~km}$ long.

The Chukou thrust (no. 29, fig. 1) is an important fault in southwestern Taiwan which is at least $75 \mathrm{~km}$ long according to Tsan and Keng (1968, p. 54). The time of its last movement is not at all clear from the evidence at hand. The Chinese Petroleum Corporation (1971) geologic map shows the fault apparently forming the contact between upper Pleistocene terrace deposits and Miocene rocks at Chukou (16 km east-southeast of Chiai), and faulting of the lower Pleistocene Erhchungchi formation $8 \mathrm{~km}$ north of Chukou. Small areas of upper Pleistocene terrace deposits along the Tsengwen River $28 \mathrm{~km}$ northeast of Tainan are not cut by the Chukou fault according to the line symbol on the Chinese Petroleum Corporation map and the map of Tsan and Keng (1968, pl. 1). To the north, the Chukou fault joins the Tachienshan fault (no. 25, fig. 1), which may cut upper Pleistocene terrace deposits near Chushan (Chinese Petroleum Corporation, 1971). The Tachienshan fault probably joins the Chelungpu-Sani fault (no. 18-21, fig. 1); if so, the Chukou fault is part of a fault system that extends at least $150 \mathrm{~km}$ and that shows evidence of Pleistocene or younger movement at various places along its length. Epicenters of several moderate to small earthquakes were located close to the Chukou fault early in 1973 (Hsiung and Lo, 1973a, 1973b). 
The 1946 Hsinhua fault (no. 30, fig. 1) has already been discussed in the section on historically active faults.

An unnamed northwest-trending fault (no. 31, fig. 1) is shown on the Chinese Petroleum Corporation (1971) map terminating the Chukou fault on the south. The unnamed fault is shown apparently cutting the lower Pleistocene Erhchungchi Formation near its northwest end.

The Houchiali fault (no. 32, fig. 1) about $4 \mathrm{~km}$ east of Tainan has an east-facing scarp about $11 \mathrm{~km}$ long developed in the Tainan Formation (Sun, 1964, p. 43; Lin, 1969, p. 115-116). Although the Tainan Formation was once considered to be of Pleistocene age (Sun, 1964, p. 40), radiocarbon dating indicates that it is of Holocene age (Lin, 1969, p. 84); this age assignment has been accepted by Sun (1972). On the basis of rather slim evidence, Sun (1964, p. 49) has suggested that the Houchiali fault may be a thrust fault dipping west. An earthquake with a magnitude in the 3 to 4 range occurred close to this fault in 1973 (Hsiung and Lo, 1973, fig. 4).

The Hsiaokangshan fault (no. 33, fig. 1) is indicated by several short west-facing fault scarps along a line about $7.5 \mathrm{~km}$ long. The scarps are developed in the Holocene Tainan formation as represented on the photogeologic map by Sun (1964). T. H. Yao, H. P. Lueng and the writer looked at the scarp about $2 \mathrm{~km}$ from its south end. At that place the scarp is very gentle but there is a definite difference in the level of the nearly-flat ground surface on the two sides of the scarp. Sun (1964, p. 49) suggested that this may be a thrust fault dipping east.

The Chinese Petroleum Corporation (1971) geologic map shows the Chishan fault (no. 34, fig. 1) displacing the lower Pleistocene Erhchungchi Formation about $20 \mathrm{~km}$ northeast of Kaohsiung but apparently not cutting upper Pleistocene terrace deposits. Nevertheless, the Chishan fault is probably active. Four earthquakes of magnitude 3 or greater were located in close proximity to this fault in 1973 (Hsiung and Lo, 1973a, 1973b).

The Liukuei fault (no. 35, fig. 1) is shown cutting a middle or lower Pleistocene formation on the geologic maps by Tsan and Keng (1968) and the Chinese Petroleum Corporation (1971); the latter map also shows the fault cutting upper Pleistocene terrace deposits. The Liukuei fault at its north end joins the Talungwan or Chaochou fault.

The Chaochou fault (no. 36, fig. 1) and its northern continuation is considered to be an east-dipping reverse fault with a left-lateral component (Tsan and Keng, 1968, p. 53-54; Meng, 1967 , p. 80, fig. 2). It has a scarp $1000 \mathrm{~m}$ to $300 \mathrm{~m}$ high forming the eastern border of the Pingtung plain. Tomita (1955) identified alluvial fans of four different ages which he believed resulted from repeated pivotal movements on the fault; Kaneko (1970, p. 217-218) suggests that the two older fans are Pleistocene and the younger are Holocene. Although Tomita does not say that the fault cuts any of the fans, movement of the fault after deposition of at least some of the fans is implicit in his explanation. Biq (1972a, p. 68-69) states that the fault is still active.

Evidence indicating recent displacement of terraces by the Chaochou fault was found using aerial photographs. This evidence was not only confirmed in the field but additional evidence of young faulting was also found. The young features are on a parallel antithetic fault that has produced east-facing scarps, rather than on the main west-facing scarps, but are believed to be related to movement on the main fault. The locality is indicated by the point of the arrow at number 36 on figure 1 , and the terraces and scarps are shown on figures 9 and 10. 

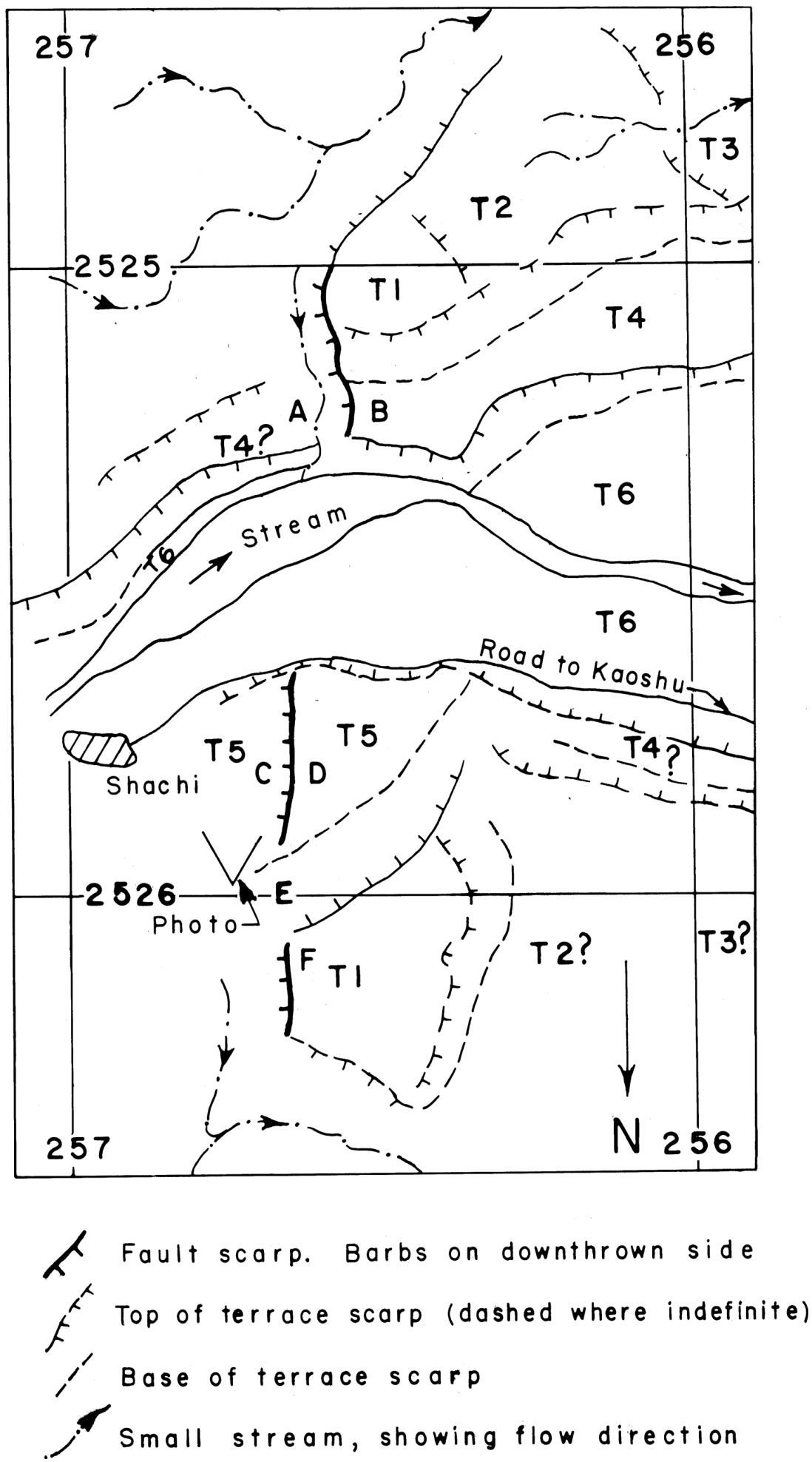

Figure 9. Map showing terraces and scarps in the Chaochou fault zone. Terraces are labeled consecutively from $T l$, the oldest and highest, to T6, the youngest and lowest. Letters A-F show localities discussed in text. Map is oriented with north at the bottom to permit easy comparison with figure 10. Lines were sketched directly from an aerial photograph and are not corrected for relief distortion. Position of Sachi village and the 1-km grid were transferred from a topographic map and are approximate only. Location of map area is indicated by arrow at fault number 36 on figure 1 . 


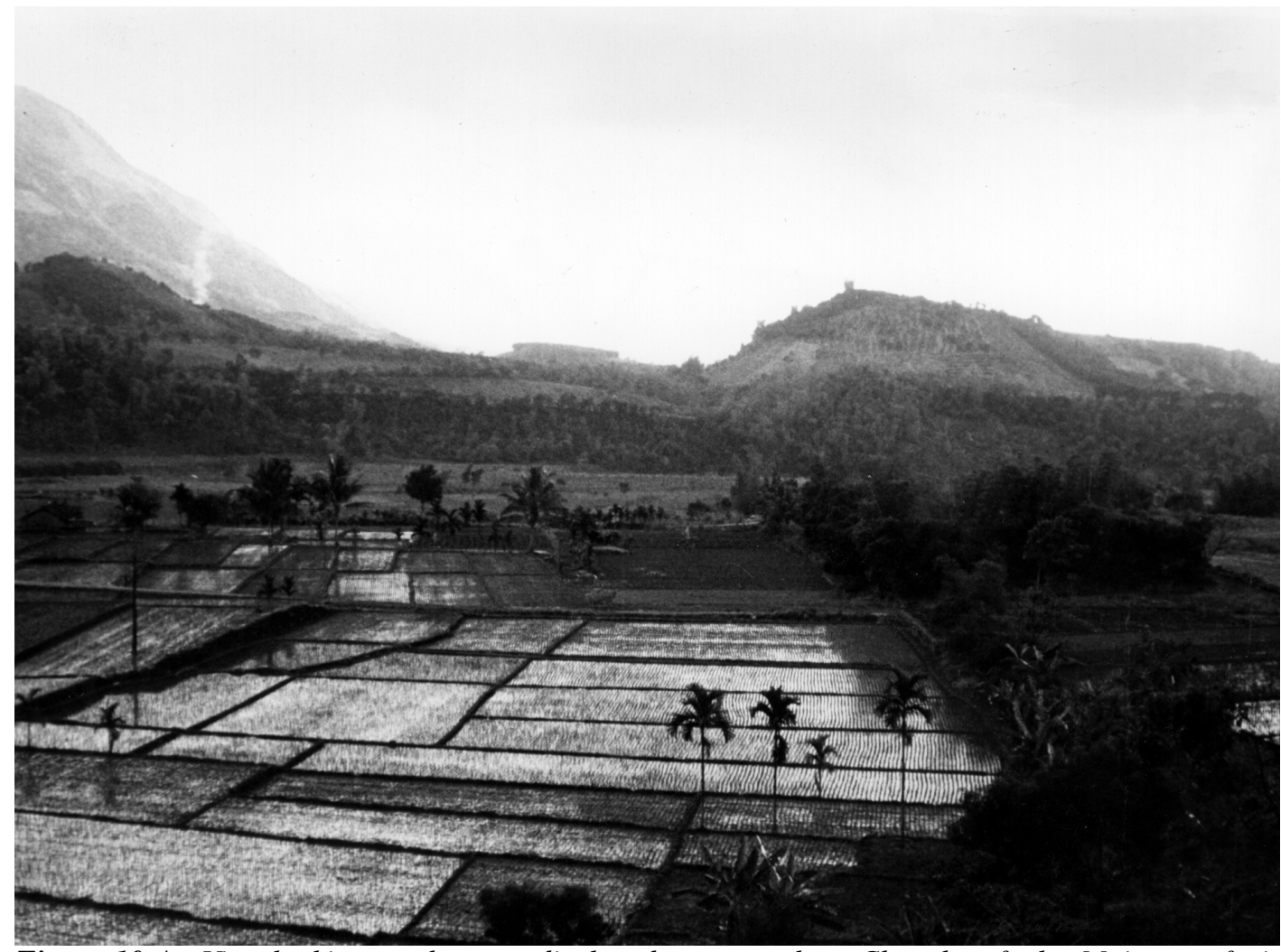

Figure 10-A. View looking southeast at displaced terraces along Chaochou fault. Main west-facing scarp of Chaochou fault faintly visible in left side of photo; east-facing scarp is along right-hand edge of rice paddy and extends to horizon with increasingly larger displacement of higher and older terraces. Photo taken January 1973.

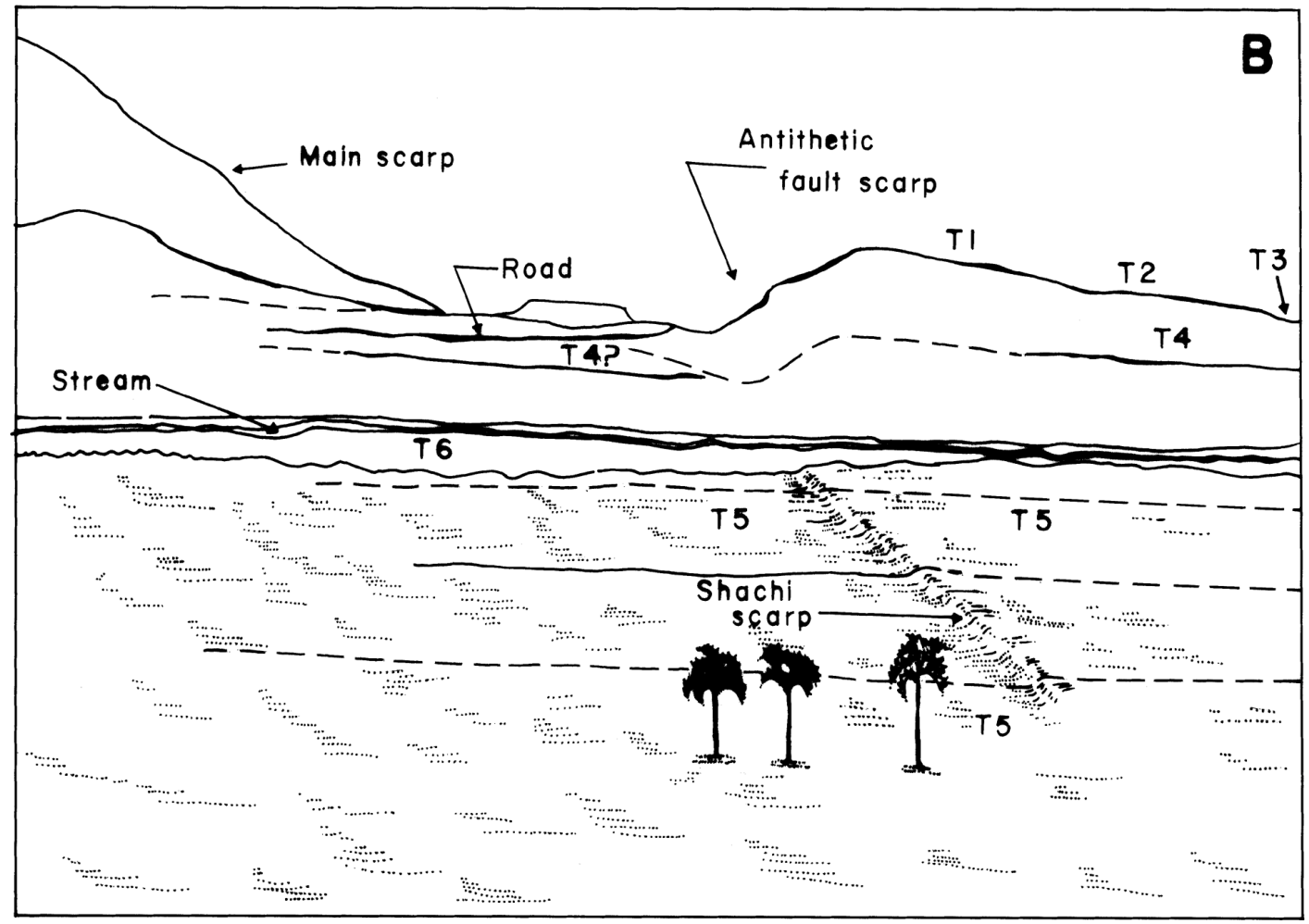

Figure 10-B. Sketch based on figure 10.A. 
Terraces along the northern part of the Chaochou fault, clearly visible on aerial photographs, are shown in part on figure 9. As seen on the aerial photos the terrace labeled T4? appeared to end abruptly against an upstream-facing scarp (between points labeled A and B on figure 9), and its apparent equivalent, T4, continued downstream from point B at a higher level. Field examination confirmed a discontinuity in the elevation of the terraces, separated by a scarp that would be very difficult to form by fluvial processes alone, but easily formed by faulting (fig. 10). Looking northward across the stream from near point $A$, it appeared that terrace $T 5$ was also interrupted by an east-facing scarp between points $C$ and $D$. A difference in the color of the soil was also seen near point E: medium gray to the west and reddish brown to the east. The color difference is in line with the scarp on T5 and the scarp that terminates terrace Tl east of point F. The scarp on terrace T5, here named the Shachi scarp, was estimated to be about $2 \mathrm{~m}$ high. Agricultural modification of the Shachi scarp and terrace T5 probably has not altered their gross form, which is incompatible with formation by fluvial processes alone.

East-facing scarps bounding high terraces such as $\mathrm{Tl}$ were seen in a few places on aerial photos of an area extending $2 \mathrm{~km}$ north and $5 \mathrm{~km}$ south of the large stream shown in figure 9, but none were seen on low terraces equivalent to T5. However, the Shachi scarp was not detected on the aerial photos, and scarps may well exist on the low terraces.

The Shachi scarp cutting terrace T5 is almost certainly Holocene and the scarp cutting T4 may be Holocene also. Both of these terraces are non-lateritic and, estimating from a topographic map with 20-m contour interval, T5 is only about $15 \mathrm{~m}$ and T4 is less than $40 \mathrm{~m}$ above T6 (the modern flood plain). Lin (1969, p. 86) considers non-lateritic river terraces less than 50 to $60 \mathrm{~m}$ in relative height to be Holocene.

The features described above indicate young activity on the Chaochou fault and some seismic data supports this inference. In 1973 four small earthquakes of magnitude less than 4 (Hsiung and Lo, 1973a, 1973b) occurred near the fault, one near the young displaced terraces and the others to the north and south of them, including one close to the south end of the fault as drawn on figure 1. All of the epicenters were several kilometers east of the fault, which may indicate an eastward dip. A brief reconnaissance in February 1974 by Ira E. Klein of the U.S. Bureau of Reclamation indicates that young terraces on the north side of the Laonung River are not displaced by the Chaochou fault near the place where it joins the Liukuei fault (Klein, 1974, personal communication), but one of the epicenters was north of this junction.

The Chaochou fault becomes less distinct toward the south. The location of its southern part, as shown on figure 1, is based on features that the writer saw on topographic maps and is approximate only. Some maps show the fault curving gently eastward to pass near Hengchun but Holocene uplift data tend to discount this (see section on tectonic uplift). Continuous seismic profiling offshore would probably fix the position of the southern part of the fault.

Two parallel northeast-trending scarps about $1 \mathrm{~km}$ apart and about $2.5 \mathrm{~km}$ long (no. 37, fig. 1) form a horst on the axis of the Chungchou anticline. As mapped by Sun (1964) they cut the Holocene Tainan Formation. Howard (1962) suggested, on the basis of drainage anomalies about $10 \mathrm{~km}$ north of the faults, that deformation of the Chungchou anticline may still be in progress. 
The Yuchang fault (no. 38, fig. 1) about $4 \mathrm{~km}$ long, displays two west-facing scarps that are developed in Holocene deposits (Sun, 1964, p.44 and pl. 1). Small west-facing scarps in Holocene deposits near Wannei (no. 39, fig. 1) were tentatively joined to the east-dipping Chinsan fault by Sun (1964).

The Fenshan fault (no. 40, fig. 1) has an east-facing scarp about $11 \mathrm{~km}$ long, at least part of which is developed in Holocene deposits. On the basis of a possible connection with the east-dipping Lungchuan thrust fault Sun (1964, p. 44) suggests that the scarp may be a fault line scarp created by erosion rather than a fault scarp.

The Chihshang fault (no. 41, fig. 1) in the southern part of the Longitudinal Valley has a well-defined scarp that has been described and illustrated by Hsu (1962). Although the age of the deposits cut by the fault is not precisely known, Hsu (1962, p. 98) concluded on the basis of geomorphology that movement has occurred in the Holocene. This fault is in line with the Yuli fault (no. 42, fig. 1) which ruptured in 1951 as described, along with number 43, under the section on historically active faults.

A gently curved valley extending southwestward from Ilan is conspicuous on topographic maps and has the appearance of a structurally controlled feature. A rapid examination of aerial photos of part of this valley did not reveal any conspicuous fault topography in the terraces along the middle reaches of the Lan Yang (or Chosui) River. Yen (1970, p. 9) has identified a significant fault in the slate formation in this vicinity and Biq (1971, fig. 1) shows a major fault there on a small-scale map. Unfortunately the writer did not have the benefit of Yen's report and maps to closely locate the fault when the aerial photos were being examined. Epicenters of earthquakes recorded in 1973 (Hsiung and Lo, 1973a, 1973b), although widely scattered, straddle the fault and suggest that it may be active.

\section{Possible Fault Creep}

Equivocal evidence was found for the occurrence of fault creep on two faults, and the writer also wishes to place on record some observations that indicate the absence of creep on at least part of some faults. Fault creep is aseismic episodic or continuous displacement along a fault at a low but varying rate. The possible fault creep noted below is presumably of tectonic origin.

\section{Longitudinal Valley fault zone}

Evidence suggestive of creep was found at the Primary School in Yuli, where the November 25, 1951, fault rupture passed through the school and damaged at least three of the buildings. The approximate position of the 1951 fault trace on the school grounds is shown on figure 11. The position of the fault was learned from the school officials based on classroom damage. The newer construction could be distinguished from the old but some classrooms not damaged by the fault movement have also been rebuilt.

The classroom at $\mathrm{C}$ on figure 11 was rebuilt in 1958; the other three rooms in this wing were built in 1950. A crack trending northwest near point $\mathrm{C}$ was first noticed in 1972, after an earthquake in April 1972, (this information is from Mr. Chang Chin-huei, Dean of Students, who also gave us dates of construction of various parts of the school and other historical data). Presumably the earthquake referred to is that of April 24 whose Richter magnitude was about 7.0 


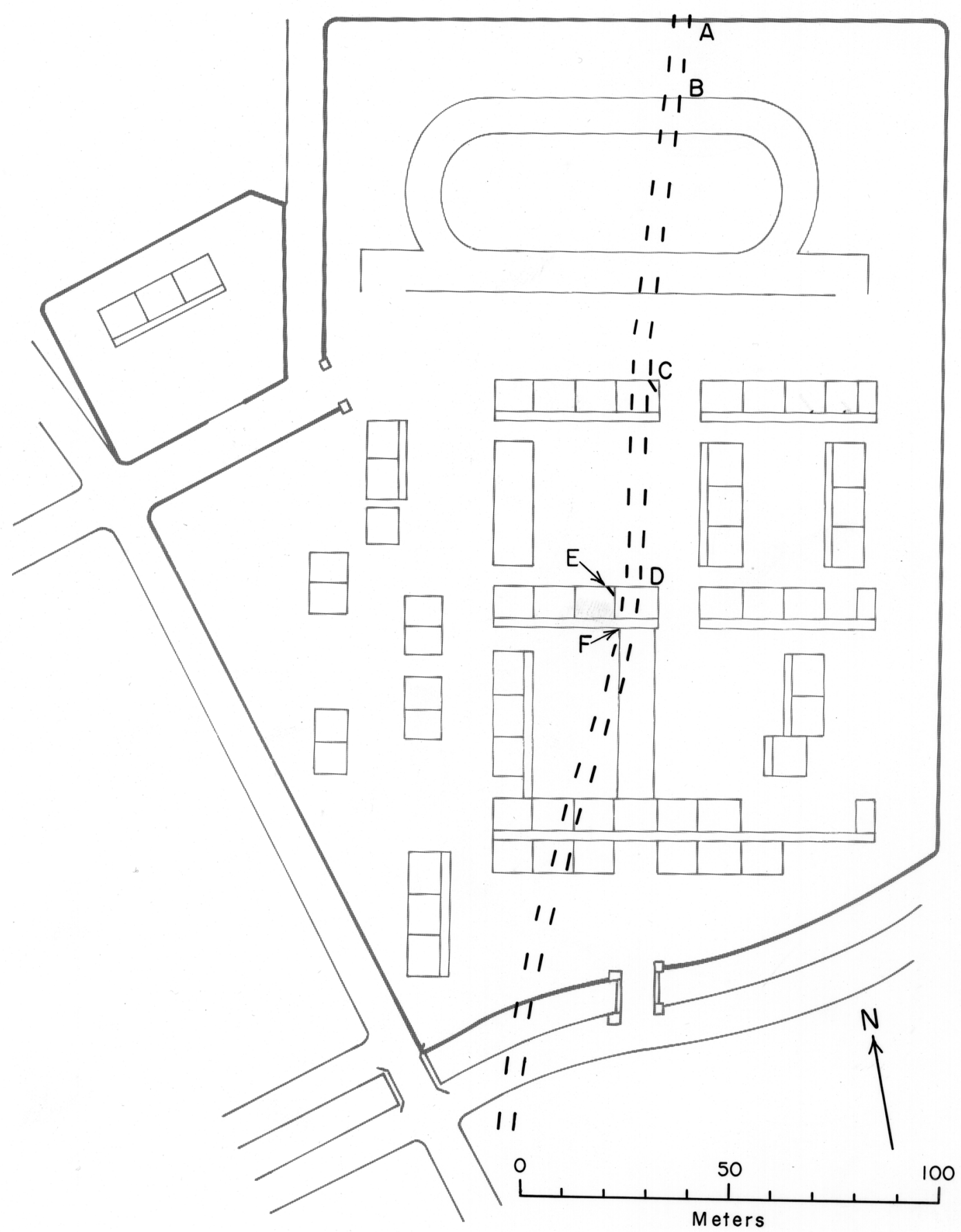

Figure 11. Map of Yuli Primary School showing approximate trace of 1951 fault rupture (double dashed line) and lettered points discussed in the text. Base map courtesy of Yuli Primary School; race track taken from 1/10,000 scale soil and land use map, 1962.

(Lander, 1972, p. 1972). The epicenter was offshore about $40 \mathrm{~km}$ north-northeast of Yuli. Variations in width at bends in the crack suggest a very small left-slip component on the crack. The northwest trend is correct for a left-lateral en echelon fracture. This crack was not found in the exterior parts of the building but small cracks showing no lateral offset were found in the foundation and gutter on the north side of the room. A north-trending crack displaced the gutter 
(but not the sidewalk nor wall) on the south side of the room about 1 or $2 \mathrm{~mm}$ in a left- lateral sense.

A crack about $6 \mathrm{~m}$ west of the northeast corner of the room at point $\mathrm{D}$ crossed the gutter, foundation, and wall below the window on the north side and extends at least $45 \mathrm{~cm}$ across the floor. This crack trended southward and had less than $1 \mathrm{~mm}$ of left slip at the gutter (fig. 12). Two other cracks crossed the gutter and foundation close to point D, and one of these also crossed the wall below a window. Neither of these two showed any lateral offset. The room at D and the three rooms to the west were rebuilt in 1962.

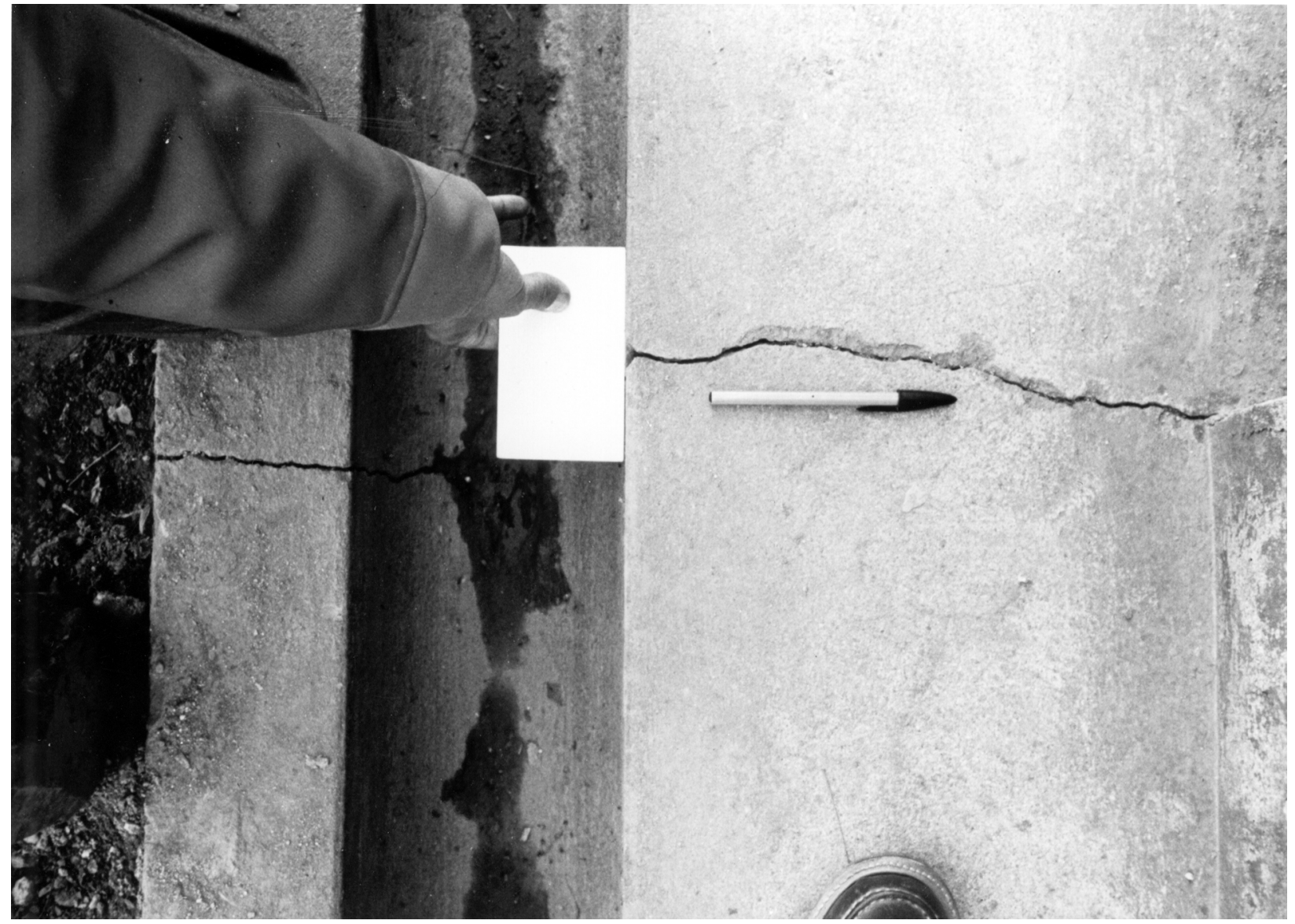

Figure 12. Photograph of crack near point D, figure 11. Small left-slip component shown by gap between card and edge of foundation on near side of crack; card is flush with edge of foundation on far side of crack.

The northwest-trending crack at point E formed in 1972 in the floor of the room but was not seen in the north wall, foundation nor gutter. This crack is properly oriented for a left-lateral en echelon system but no lateral displacement was noted along it.

About $2 \mathrm{~m}$ west of point $\mathrm{F}$ a north-trending crack showed $4 \mathrm{~mm}$ of left slip. This crack crossed the concrete gutter and sidewalk but did not seem to enter the wall. Another crack $7 \mathrm{~m}$ west of point $\mathrm{F}$ crossed the gutter and concrete sidewalk but did not have a direct continuation through the wall. It showed $1 \mathrm{~mm}$ of left slip.

Point $\mathrm{F}$ is at the north end of a stone masonry walk that was completed in January 1972. Soon after completion cracks formed in the concrete gutter that is in contact with the walk, and 
the edge of the gutter was pushed northward at and east of point F. The cracks had been filled prior to the April 1972 earthquake, when additional cracking occurred. More cracking occurred between April 1972 and January 1973, when the photograph (fig. 13) was taken. The cracking

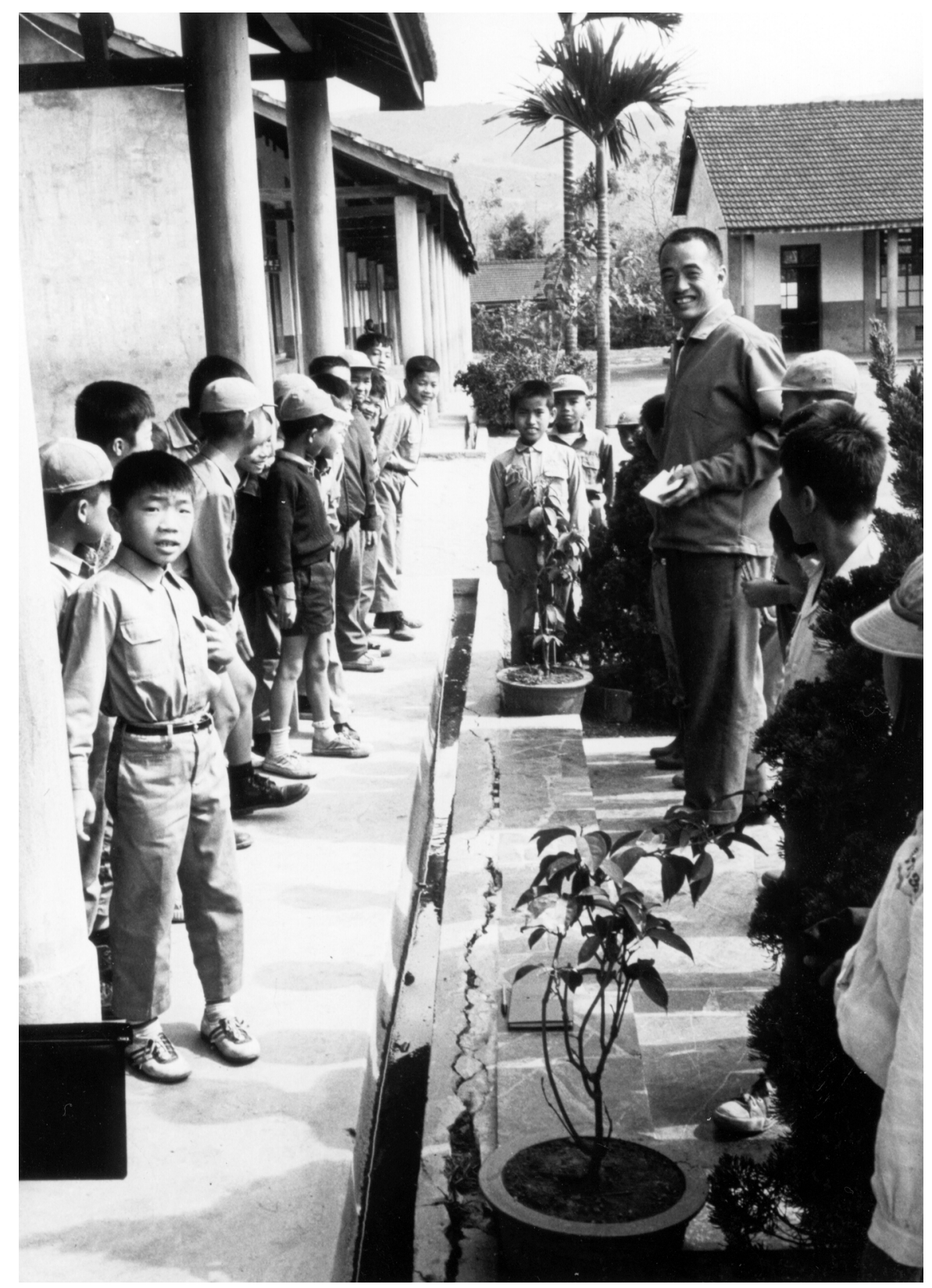

Figure 13. Cracking at north end of stone walk. The narrowing of the gutter can be seen opposite the walk, which enters the photo from the right. Photo taken January 17, 1973.

may be the result of thermal expansion of the walk combined with some tectonic creep. Using the highest thermal coefficient for rocks $\left(11 \times 10^{-6}\right)$ listed by Clark (1966), a $12{ }^{\circ} \mathrm{C}$ difference in average temperature between January and July (Chang, 1972, pl. B3), and a length of $40 \mathrm{~m}$ for the walk indicates that a thermal expansion of about $5 \mathrm{~mm}$ could occur. The amount of northward displacement of the edge of the gutter was not measured in the field but judging from the photograph it is considerably more than the $5 \mathrm{~mm}$ that might result from one cycle of thermal 
expansion alone; however, if the cracks were repeatedly filled with noncompressible material the effects of expansion would be additive. Whatever the cause of the large displacement of the walk, it seems clear that creep alone is not sufficient.

A bend in the north edge of the race track at the Yuli school is interpreted as an effect of the 1951 faulting rather than fault creep. The east-west trending edges of the race track are marked by single rows of pebbles that are set into the ground. All of these rows of pebbles are straight except the northernmost one which, at point B (fig. 11), has a left-lateral bend of about $16 \mathrm{~cm}$ (fig. 14). The custodian said that the pebbles on the south side of the north portion of the track had been realigned in 1972 but the northern row of pebbles near point B has not been disturbed for many years. The amount of fault displacement that occurred at the Yuli school in 1951 is not well documented in the literature. The Taiwan Weather Bureau (undated) report on the 1951 earthquake has a photograph of a 40-cm left slip fault displacement of one of the school buildings. Another photograph, given to the writer by T. L. Hsu, shows the borders of a flower bed displaced some 15 or $20 \mathrm{~cm}$. If the flower bed was cut by the main fault, then the amount of displacement on the fault varied considerably within the school grounds and the $16-\mathrm{cm}$ bend in the row of pebbles can represent the entire fault displacement in that part of the school. Structures nearby indicate that no more than a small fraction of the bend can be attributed to fault creep. Less than $20 \mathrm{~m}$ north of the row of pebbles, at point A, is a concrete block wall, built about 1968, which shows no bends or cracks that can be attributed to creep. The classroom at point $\mathrm{C}$, built in 1958, shows less than $1 \mathrm{~cm}$ of deformation that may be the result of creep. The bend in the row of pebbles at point B is interpreted as an effect of the 1951 faulting which was preserved there but which has been obliterated from the other rows of pebbles by post-1951 realignment. This interpretation is based on the main points discussed above: The bend falls at the position of the fault indicated by the school officials, the sense of displacement is the same as the 1951 faulting, and the amount of displacement is compatible with the 1951 displacement but not with creep displacement.

A search was made on foot for evidence of 1951 fault displacement and fault creep in the village of Jui-mei (1.5 km east of Jui-sui, fig. 8) and along $0.7 \mathrm{~km}$ of the road from Jui-mei to Jui-sui, but we found none. Some cracks were found in the eastern pillar and western wall (both of concrete) at the entrance to the elementary school at Jui-mei but the cracks did not have a consistent lateral offset and they were not found in the concrete base of the structures nor the asphalt paving of the road. Although we made a circuit on foot of Jui-mei we found no other evidence even suggestive of fault creep.

The north end of the October 22, 1961 fault scarp (no. 42, fig. 1) at Chihsingt'an was examined briefly but the conditions at the point of examination were such that the presence or absence of creep could not be established.

\section{Western Taiwan}

No compelling evidence of fault creep was found at points on three faults in western Taiwan where such evidence was sought, but creep may have occurred along part of one fault. The Hsinhua Experimental Farm, about 7 km northeast of Hsinhua (B, fig. 7), lies across the 1946 trace of fault rupture mapped by Chang, Chow, and Chen (1947). All of the paved roads, walks, and fences and nearly all of the buildings at the farm have been built since the 1946 earthquake and faulting. Mr. H. P. Lueng noticed that one of the pre-1946 buildings has some east-trending 
cracks in the foundation that show right-lateral displacements estimated to be about 1 or $2 \mathrm{~mm}$. Some of the cracks were formed or widened during an earthquake in 1964, according to personnel at the farm. The 1964 earthquake was of Richter magnitude 6.3 and its epicenter was about $18 \mathrm{~km}$ east-northeast of the farm at lat. $23.1^{\circ} \mathrm{N}$., long. $120.5^{\circ} \mathrm{E}$ (Hsu, 1971, p. 145).

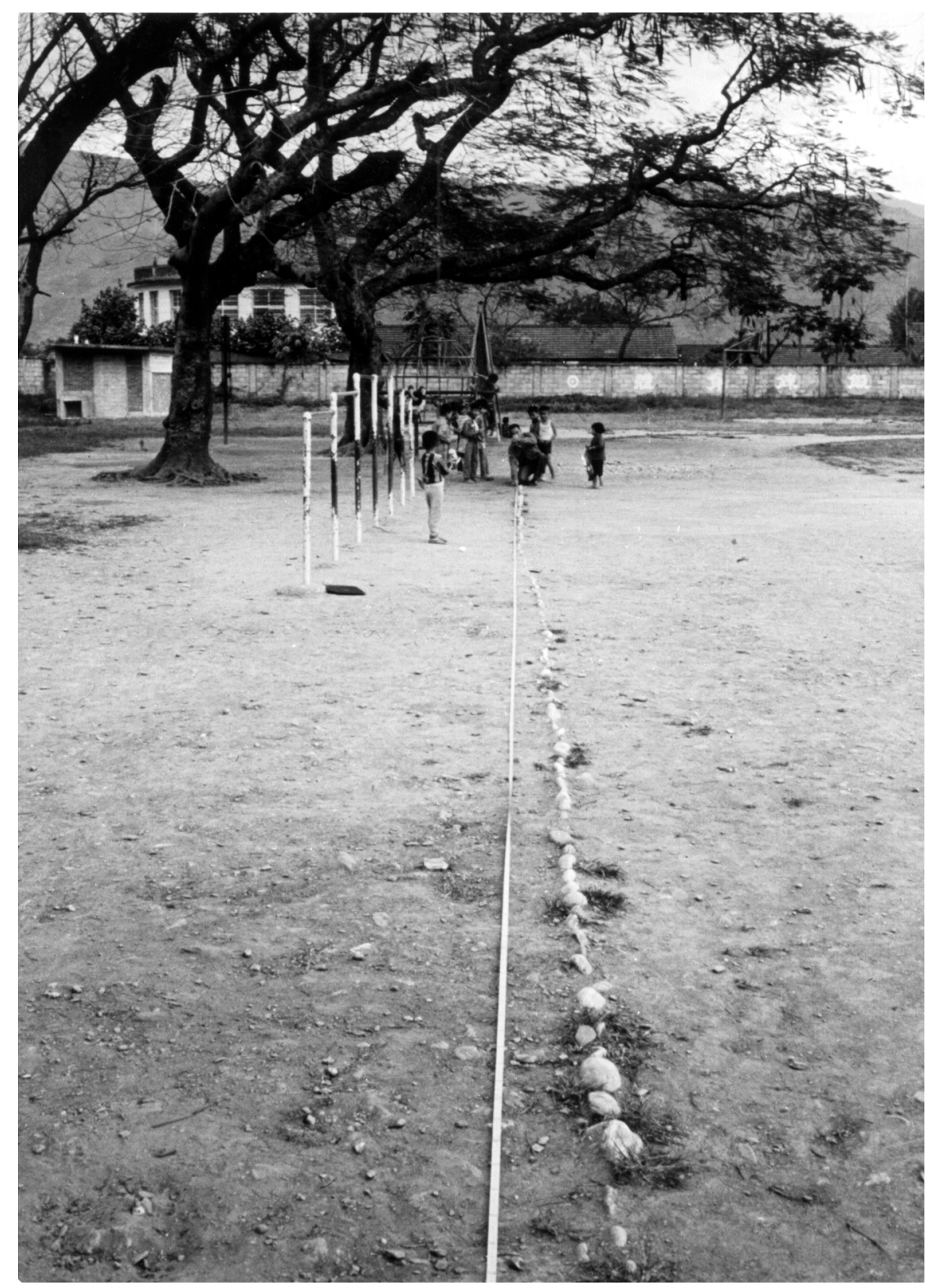

Figure 14. Bend in line of pebbles marking north side of race track at Yuli Primary School. Tape is in line with edges of pebbles in the background, but is $16 \mathrm{~cm}$ from pebbles in the foreground.

A north-south fence on the Experimental Farm provides interesting but puzzling evidence suggestive of creep displacement. The fence apparently consists of two straight segments which are misaligned right-laterally by an amount nearly equal to the width of the concrete posts (10 $\mathrm{cm})$. Mr. S. H. Chou, who participated in the construction of the fence in 1968, said that the 
posts were placed in a line formed by stretching a wire from one end to the other. The present appearance of the fence is very similar to many fences in California that have been displaced by tectonic creep on the San Andreas fault; however, a parallel fence also built in 1968 some tens of meters to the east shows no such bend, nor do the north-south sidewalk and row of buildings that are immediately west of the fence. The eastern fence is divided into a north and a south segment by an east-west road, and the hypothetical zone of creep might be stepped en echelon and pass undetected under the east-west road. The topography prevents checking the alignment of the north and south segment of the fence by eye alone. If the sidewalk and row of buildings west of the misaligned fence were built later than the fence the lack of offset in them could be explained, but we do not know this to be so. No clear field evidence of the position of the 1946 fault trace was found at the farm. Transfer of the trace from the 1/50,000 scale map of Chang, Chow, and Chen (1947, pl. 3) to a topographic map of the same scale indicates that the pre-1946 building with the cracks in the foundation mentioned above is close to the 1946 trace and that the misalignment in the fence is perhaps $150 \mathrm{~m}$ south of the 1946 trace.

No evidence for fault creep was found at four places that were examined along the 1906 fault trace. En echelon cracks, which commonly are found in asphalt pavement overlying creeping faults in California, were not found where the Meishan-Talin road crosses the 1906 trace about $1 \mathrm{~km}$ northwest of Meishan (point A, fig. 2). The position of the fault can be closely located there because the south-facing part of the scarp is still visible west of the highway (fig. 3 ). About $0.4 \mathrm{~km}$ west of the highway the fault passes under the village of Weichuang (also called Sanmei). This village, called Bisho in 1906, was completely destroyed by the earthquake and faulting of 1906 (Omori, 1907, p. 57). We found no field evidence of the position of the fault at the village but a general reconnaissance of walls, foundations, and threshing floors made of concrete revealed no evidence of fault creep. The narrow-gauge railroad that crosses the 1906 trace $0.7 \mathrm{~km}$ southeast of the village of Maliao (point C, fig. 2) shows no effects of creep. The exact position of the fault at that place is unknown because the $1.22 \mathrm{~m}$ scarp shown in this vicinity on figure 2 of Omori (1907) has evidently been obliterated by farming. The length of straight track there however, assures that the fault was crossed during our examination. A small area near the primary school in the southern part of Minhsiungchen (point E, fig. 2) was examined. This area is just west of the west end of the definite surface faulting as mapped by Omori (1907) but directly in line with it. A right-lateral bend was found in a north-south brick wall but the bend was apparently built in rather than being caused by creep. No other evidence even suggestive of creep was found there.

The Touhuanping fault (no. 13, fig. 1) has a well developed straight scarp in the village of Touhuanping, about $14 \mathrm{~km}$ south of Hsinchu. Tang (1968, p. 78) has concluded that renewed displacement has occurred on this fault in Recent (Holocene) time. A concrete building straddling a leveled part of the scarp shows no obvious vertical distortion; a concrete road across another part of the scarp has some cracks but they have no vertical displacement across them. If creep is occurring at the two sites mentioned, the rate of movement must be slow.

The writer was not able to examine the 1935 faults for evidence of creep.

\section{Tectonic Uplift and Subsidence}

Tectonic uplift or subsidence can have serious practical consequences and therefore the topic is included here even though it is peripheral to the main subject of this report. The geologic 
and historic record shows that tectonic uplift and probably subsidence have occurred recently in Taiwan. Important questions are whether the uplift occurred slowly or suddenly and, if suddenly, what the amount was. A large sudden uplift, for example, might raise the cooling-water intake of a nuclear power reactor above sea level with possibly disastrous consequences, or might make harbor facilities useless and cause great economic loss. Some of the geologic and historic information that relates to these questions is discussed in the paragraphs that follow.

Geologic information shows that vertical tectonic movements have occurred in Taiwan in late Quaternary time and that the movements have not been the same throughout the island. Hsu (1962 b) has identified 10 types of coast in Taiwan on the basis of geomorphology. He found that 6 of these types show emergence, two show submergence, and two are neutral; further, the uplift within the areas of emergence is commonly unequal (Hsu, 1962 b, p. 37, 38, 40; 1954, p. 55). The unequal change in relation to sea level shows that the vertical movement cannot be entirely eustatic - some of it must be tectonic. Eustatic sea level in the last 20,000 years has not been more than $3 \mathrm{~m}$ above present sea level according to Fairbridge (1961, fig. 15); data from Japan (Fujii, Lin, and Tjia, 1971, fig. 1) suggests that sea level 5 to 6 thousand years ago was about $3 \mathrm{~m}$ above present sea level.

Morner (1971, p. 66 and fig. 4), working in Scandinavia where non-eustatic factors can be closely evaluated, concluded that the highest eustatic sea level in the last 20,000 years was only $0.4 \mathrm{~m}$ above present sea level. Accepting Morner's data as correct, assuming that the relation between the eustatic level in Scandinavia and Taiwan has not changed significantly in the period of interest, and considering the tidal range of about $5 \mathrm{~m}$ on the west coast of Taiwan and about $1 \mathrm{~m}$ elsewhere (Hsu, 1962b, p. 36), it follows that the fossiliferous marine deposits in Taiwan less than 20,000 years old that are more than $3 \mathrm{~m}$ above mean sea level on the west coast and more than 1 $\mathrm{m}$ above mean sea level on the other coasts have been uplifted tectonically.

Radiocarbon dates on marine deposits coupled with the eustatic sea level curves of Morner (1971) permit identification of many of the areas of Holocene tectonic uplift in Taiwan and calculation of approximate minimum rates of uplift. Using the reasonable assumption that the fossiliferous marine deposits were formed at or below mean sea level, the calculations yield the values given in table 1; these values are also shown on figure 1. The principal unknown factor in these data is the depth below sea level at which the deposits formed. Konishi and others (1968, table 1) used a range of 0 to $2 \mathrm{~m}$ in making calculations of rate of uplift, and the actual depth could have been even greater. The effect of this uncertainty is that the actual uplift rates could have been greater than the calculated rates. Despite this defect and the scanty data some interesting contrasts and similarities in different parts of Taiwan are apparent on figure 1. In northern Taiwan localities A, B, and Q show minimum uplift rates ranging from 2.1 to $3.1 \mathrm{~mm} /$ yr. but locality $\mathrm{C}$ shows only $0.4 \mathrm{~mm} / \mathrm{yr}$. This suggests differential vertical movements between locality $\mathrm{C}$ and the others in Holocene time and the possibility of active faulting. The Chaochou fault (no. 36, fig. 1) is shown on some maps as passing through the lowland in which the town of Hengchun lies. The uplift rates on the east side of the lowland (localities F, G, H, K, and L) are not greatly different from the rates on the west side (localities I and J); this suggests that the fault does not pass through the lowland, or if it does the vertical movement on it has not been great in Holocene time. The average rate (about $4 \mathrm{~mm} / \mathrm{yr}$.) for the localities adjacent to the lowland is in contrast to locality E ( 2.0 or $2.8 \mathrm{~mm} / \mathrm{yr}$.) and suggests differential vertical movement of locality $\mathrm{E}$ with respect to the others. Locality D, near the 1951 faulting, and locality P, near the 1946 
faulting, both have high rates of uplift. The equally high rate at locality $\mathrm{N}$ suggests that it too is in a tectonically active area.

Historic information shows that vertical tectonic displacements have accompanied at least one and perhaps two earthquakes in Taiwan. An uplift of $0.6 \mathrm{~m}$ relative to sea level was apparent at the Hualien Harbor after the earthquake of October 22, 1951 (Hsu, 1954, p. 57) and the uplift was probably $1.2 \mathrm{~m}$ at Chihsingtan, north of Hualien, adjacent to the Meilun fault which had that amount of displacement (see description of the faulting elsewhere in this report). Downward vertical movement related to an earthquake occurred in the Taipei basin in 1694 (Lin, 1969, p. 114). Information obtained by T. H. Yao (1973, personal communication) indicates, with considerable uncertainty, that the subsidence could have been as much as $1.5 \mathrm{~m}$. The information that the writer has does not eliminate compaction or other superficial processes as possible causes for the 1694 subsidence. Tectonic subsidence is a very reasonable possibility in view of the geologic evidence of structural subsidence of the Taipei basin cited by Huang (1962, p. 149) and despite the evidence of tectonic uplift a short distance to the east at locality A (table 1 and fig. 1).

The geologic and historic data outlined above indicate that vertical tectonic movements have occurred in Taiwan in the last 10,000 years and that in some places the movement was sudden and accompanied by earthquakes. Whether sudden displacements have happened in many parts of the island is an unanswered question. The apparently similar rate of uplift calculated for widely separated parts of Taiwan does not by itself mean that sudden uplift has not occurred; sudden vertical displacements accompanying earthquakes in Alaska and Chile have produced elongated areas of uplift and subsidence whose long dimension was greater than the length of Taiwan and in which the vertical displacement varied little longitudinally (Plafker, 1969; Plafker and Savage, 1970). Assuming that sudden uplifts have affected many parts of Taiwan, another unknown is the amount of uplift that has occurred in individual jumps in the past and therefore may occur in the future. An idea of the practical upper limit can be obtained from the largest sudden uplift that has been recorded anywhere in the world, $14 \mathrm{~m}$, which occurred in Alaska in 1899 (Tarr and Martin, 1912) and from another large uplift, $12 \mathrm{~m}$, which occurred there in 1964 (Plafker, 1969). Until more information is developed the low end of the range might be taken as 1 $\mathrm{m}$ based on the 1951 uplift, at least in the Hualien area. The range in the calculated long-term uplift rate (table 1 and fig. 1) suggests that the amount of sudden uplift that may occur will be different at different points on Taiwan.

\section{Summary and Conclusions}

The study of active faults and of the location and other characteristics of earthquakes is an essential part of an earthquake-hazard reduction program because it provides a basis for anticipating the location of future earthquakes, surface faulting, tectonic uplift, landslides and other ground failures. This report summarizes information on two of these phenomena, surface faulting and tectonic uplift. Although based on incomplete evidence, it can serve as background for further investigations related to seismic hazards in Taiwan and calls attention to some problems that may be encountered in other areas as well.

More than 40 faults that, according to the literature, cut Pleistocene or Holocene deposits on Taiwan are identified in the report. Using a conservative set of criteria, some of these faults are known to be active but many will no doubt prove to be inactive when further investigations are made. Nearly all of these faults are in the western part of Taiwan. 
In the period from 1906 through 1951, six of the forty-odd faults discussed above ruptured the ground surface. The maximum fault displacements at the surface ranged from 1 to 3 $\mathrm{m}$ and the associated earthquakes had magnitudes ranging from 6.3 to 7.3. The earthquakes caused nearly 4,400 deaths and destroyed more than 28,000 houses; 99 percent of the deaths and 95 percent of the destruction of houses occurred in western Taiwan.

Study of the surface faulting that has occurred in Taiwan shows that recognition of faults capable of surface rupture can be quite difficult, that geologic investigations done for other purposes may not discover such faults, and that large displacements can occur on faults that do not have great formational differences across them. Geologic investigations in western Taiwan during the last 20 years or so have been primarily for petroleum exploration. These investigations have included gravity and seismic surveys, field geologic mapping, photogeologic mapping, and some drilling. This work has been done by persons who did not have access to reports describing historic faulting in the area and thus the situation can be likened to investigating an area prior to surface faulting.

The 1906 surface faulting in western Taiwan has a maximum displacement of $2.7 \mathrm{~m}$ and was more than $13 \mathrm{~km}$ long. None of the techniques mentioned above detected any part of this fault but seismic surveys revealed buried parallel faults. An investigation whose primary goal was to find faults might have concluded that a fault existed there because, with hindsight, one can find some geologic relations and landforms that suggest a fault.

In 1935 two ruptures occurred in western Taiwan. The southern rupture was $12 \mathrm{~km}$ long, had a right slip of $1.5 \mathrm{~m}$ and occurred on a nearly flat coastal plain. No scarps, differences in terrace levels, stream offsets, formation differences, nor the existence of the coastal plain portion of the fault is reported in the modern literature. The rupture crossed, at $55^{\circ}$ angle, a thrust fault known to displace Pleistocene deposits and extended into the hill front where it coincided, for about $0.9 \mathrm{~km}$, with a mapped right-slip fault. The northern fault, which occurred in a hilly area, was $15 \mathrm{~km}$ long and had a reverse displacement of $3 \mathrm{~m}$. This fault occurred between and parallel to two faults that are shown on modern geologic maps, but it was $0.6 \mathrm{~km}$ to $1 \mathrm{~km}$ from the nearer one. A short segment, separated from the main continuous rupture, was approximately coincident with a mapped fault for about $1.5 \mathrm{~km}$. The northern fault occurred along a prominent side-hill ridge that may be a fault scarp, but the ridge is made up of resistant sandstone and there are similar sandstone ridges in the vicinity that are the result of differential erosion. The formations on the two sides of the rupture are similar; both are Tertiary marine sediments.

The 1946 faulting in western Taiwan had a maximum net surface displacement of $2.14 \mathrm{~m}$, a surface trace $6 \mathrm{~km}$ long and a total length of at least $12 \mathrm{~km}$. Surface evidence of the fault is obscure at best and it is not shown on geologic maps published in 1964 and 1971. A structural contour map based on seismic surveys, however, shows a buried fault with post-Pliocene movement that apparently coincides with the subsurface extension of the surface faulting.

Of the $46 \mathrm{~km}$ or more of historic surface faulting that has occurred in western Taiwan, only about 5 percent of it coincides with faults shown on recent geologic maps. This low percentage is not a reflection of the quality of the geologic and geophysical work. It may reflect the fact that the purpose of the work was not the investigation of young faulting, and that most of the ground surface has been modified by intensive agricultural activities. Another possibility is that the surface faulting occurred on poorly developed faults close to well-developed faults, or 
even broke, in part, through previously unfaulted rock. These possibilities have important implications for land-use planning wherever active faults exist and it would be very beneficial to carefully investigate the evidence in Taiwan.

In addition to the historically active faults, the other faults that apparently cut Holocene and Pleistocene deposits need to be investigated. Their location, limits, time of most recent activity, sense and amount of displacement, and associated seismicity all need to be known to evaluate their future behavior. Accurate determination of seismicity is already under way and the other factors can be established by further use of techniques such as use of aerial photos to aid geomorphological studies, field mapping of critical areas, search for fault creep, studies of differential vertical uplift of Holocene marine terraces and fossils, geophysical studies including offshore work, and drilling and trenching of selected areas. These studies will permit better definition of the faults, a reappraisal of their degree of activity, and the probable discovery of as yet unrecognized active faults. A high priority should be given to studies in western Taiwan because of the greater number of: 1) people, 2) historic surface fault ruptures, 3) late Quaternary faults, and 4) deaths and destruction from earthquakes in the western compared to the eastern part. However, study of the Longitudinal Valley and the eastern offshore area, which seem to be at or near a plate boundary, is important for understanding the general tectonic setting. This understanding may be necessary to evaluate the possibility and location of sudden vertical tectonic movements.

Geologic evidence, based on geomorphology and quantitative data on vertical displacements of marine deposits, shows that differential vertical tectonic movements have occurred in Taiwan in the last 10,000 years. Some of the vertical movement has occurred at the same time as historic earthquakes and has amounted to about $1 \mathrm{~m}$. Future movements could well be much more than $1 \mathrm{~m}$ considering that uplifts of as much as $14 \mathrm{~m}$ have accompanied earthquakes in other parts of the world. Sudden large uplifts can have very serious consequences for nuclear reactors or harbor facilities and a study of the process as it affects Taiwan seems a necessary part of earthquake hazard reduction. The principal, and difficult, questions to be answered are what parts of the island have been affected by sudden uplift and how much has occurred in individual increments of movement.

Other processes related to earthquakes that have caused deaths or destruction in Taiwan are seismic sea waves, landslides, and liquefaction. These are all outside and scope of this paper, but need to be considered in establishing priorities for geologic work related to earthquake hazard reduction.

\section{References cited}

Allen, C.R., 1962, Circum-Pacific faulting in the Philippines-Taiwan region: Jour. Geophys. Research, v. 67, no. 12, p. 4795-4812.

Biq, Chingchang, 1971b, Some aspects of post-orogenic block tectonics in Taiwan: Royal Soc. New Zealand Bull. 9, p. 19-24.

1972a, Dual-trench structure in the Taiwan-Luzon region: Geol. Soc. China Proc. no. 15., p. 65-75.

1972b, Western Taiwan thrusts., active or inactive?: Acta Geologica Taiwanica., no. 15

(April 1972), p. 63-75. 
Bonilla, M.G., 1970, Surface faulting and related effects, in_Wiegel, R.L., ed., Earthquake Engineering, Englewood Cliffs, N.J., Prentice-Hall, p. 47-74.

Bonilla, M.G., and Buchanan, J.M., 1970, Interim report on worldwide historic surface faulting: U.S. Geol. Survey open-file report, $32 \mathrm{p}$.

Chang, C.Y., ed., 1972, The National Atlas of China., Volume 1, Taiwan., Fourth Edition: Yang Ming Shan, Taiwan, The National War College.

Chang, Li-Sho., Chow, Minchen, and Chen, Pei-Yuan, 1947, The Taiwan earthquake of December 5, 1946: Taiwan Geol. Surv. Bull. no. 1, p. 17-20.

Chang, S.S.L., 1971, Subsurface geologic study of the Taichung Basin, Taiwan: Petrol. Geol. Taiwan, no. 8, p. 21-45.

Cheng, Ke-Chieh, 1960, Report on the 1951 earthquake in Taiwan: World Conf. Earthquake Eng., 2nd, Japan, 1960, Proc., v. 1, p. 397-408.

Chinese Petroleum Corporation, 1971, Geological map of western Taiwan: Chinese Petrol. Corp., Miaoli, Taiwan, China, 1:200,000.

Chiu, H.T., 1972, Miocene stratigraphy of the Nantou area, central Taiwan: Petroleum Geol. of Taiwan, no. 10, p. 159-177.

Chou, J.T., 1973, Sedimentology and paleogeography of the Upper Cenozoic system of Western Taiwan: Geol. Soc. China Proc., no. 16, p. 111-143.

Clark, S.P., Jr., ed., 1966, Handbook of physical constants: Geol. Soc. America Mem. 97.

Earthquake Research Institute, 1936, Papers and reports on the Formosa earthquake of 1935: Tokyo Univ., Earthquake Res. Inst. Bull., Supp. Vol. III, 238 p.

Fuji, Shoji, Lin, C.C., and Tijia, 1971, Sea level changes in Asia during the past 11,000 years: Quaternaria, v. 14, p. 211-216.

Gagel, C., 1912, Das Erdbeben von Formosa am 17 Marz 1906: Deutsch. Geol. Gesellsch., Zeitschr., v. 63, p. 552-557.

Hashimoto, Wataru, 1972, Problems on the Tainan Formation and related formations, brought about by ${ }^{14} \mathrm{C}$ dating: Acta Geologica Taiwanica, no, 15, p. 51-62.

Hashimoto, Wataru, Taira, Kuzuhiro, Kurihara, Kenji, Imai, Toyoji, and Makino, Yasuhiko, 1970, Studies on the younger Cenozoic deposits in Taiwan (Formosa): Part I. The younger Cenozoic deposits of the middle part of West Taiwan: Geol. and Pal. of Southeast Asia, v. VIII, p. 237-252.

Hashimoto, Wataru, Taira, Kazuhiro, Kurihana, Kenji, Imai, Toyoji, and Makino, Yasuhiko, 1972, Studies on the younger Cenozoic deposits in Taiwan (Formosa): Part II. The younger Cenozoic deposits in South and East Taiwan: Geol. and Pal. of Southeast Asia, v. 10, p. 265-303.

Hayasaka, Ichiro, 1935, A geological note on the Taiwan earthquake of April 21, 1935: Imp. Acad. Tokyo, Proc., v. 11, no. 7, p. 265-267.

Ho, C.S., 1959, Thrust structures in Taichung and Nantou, central Taiwan: Taiwan Geol. Survey Bull., no. 11, p. 65-80. 1969, Some stratigraphic-structural problems of the Linkou terrace in northern Taiwan: Geol. Soc. China Proc., no. 12, p. 65-80.

Howard, A.D., 1962 The Chungchou photogeologic anomaly: Mr. K.Y. King's 60th Birthday Jubilee Volume (1) Petroleum geology of Taiwan, p. 121-125.

Hsiao, P.T., 1970, Seismic study of the area between the coastal plain and the foothills, Chiayi, Taiwan: Petroleum Geol. Taiwan, no. 7, p. 47-52. 
Hsiung, Yun-mei, and Lo, Chun-moo, 1973a, Catalog of earthquakes in Taiwan, January to March, 1973: Chinese Earthquake Research Center, Academia Sinica, report EIT No. 73-1.

Hsiung, Yun-mei, and Lo, Chun-moo, 1973b, Catalog of earthquakes in Taiwan, April to June, 1973: Chinese Earthquake Research Center,, Academia Sinica, report TE No. 73-2.

Hsu, Ming-Tung, 1971, Seismicity of Taiwan and some related problems: Bull. Intern. Inst. Seismol. and Earthq. Eng., v. 8, p. 41-160.

Hsu, T.L., 1954, On the geomorphic features and the recent uplifting movement of the Coastal Range, Eastern Taiwan: Taiwan Geol. Surv. Bull. no. 7, p. 51- 57. 1955, The earthquakes of Taiwan: Bank of Taiwan Quart. J our., v. 7, no. 2, pp. 148-164. 1962a, Recent faulting in the Longitudinal Valley of eastern Taiwan: Geol. Soc. China Mem. no. 1, p. 95-102. 1962b, A study of the coastal geomorphology of Taiwan: Geol. Soc. Taiwan Proc., no. 5, p. 29-45.

Hsu, Yuin-Chi, Huang, C.Y., Lin, S.Y., Hsu, Yi-Chuan, Chou, M.C., Lu, S.C., and Tai, Y, K., 1965, Low background counter for carbon-14 dating: Chinese Journ. Physics, v. 3(1), p. $1-9.55$

Huang, T.C., 1962, The Sungshan formation in the Teipei basin: Geol. Soc. China Mem., v. 1, p. 133-151.

Iida, Kumizi, 1959, Earthquake energy and earthquake fault: Nagoya Univ., Jour. Earth Sci., v. 7., no. 2. p. 98-107.

Kaneko, Shiro, 1970, Transcurrent buckling and some notes on neotectonics in Taiwan (Formosa): Japan Geol. Soc. Jour., v. 76, no. 4, p. 215-222.

Konishi, Kenji, Omuro, Akio and Kimura Tashio, 1968, ${ }^{234} \mathrm{U}-{ }^{230} \mathrm{Th}$ dating of some late Quaternary coralline limestone from southern Taiwan (Formosa): Geol. and Pal. Southeast Asia, v. 5, p. 211-224.

$\mathrm{Ku}$. C.C., 1963, Photogeologic study of terraces in northwestern Taiwan: Geol. Soc. China Proc. no. 6. p. 51-60.

$\mathrm{Ku}$, C.C., 1964, Observations on the terranes and recent tectonic movement of the Coastal Range of Taiwan: Mainly photogeological: Geol. Soc. China Proc., no. 7. p. 73-79.

Lander, J.F., 1972, Seismological notes - March-April 1972: Seismol. Soc. Amer. Bull., v. 62, no. 6. p. 1789-1792.

Lin., C.C., 1963, The Lungkang formation, lower marine terrace deposits near Miaoli: Petroleum Geol. of Taiwan, no. 2, p. 87-105. 1969, Holocene geology of Taiwan: Acta Geologica Taiwanica, no. 13, p. 83- 126.

Ma., T.Y.H., 1967, The two fundamental laws of earth evolution derived from the formation of peneplains and deposition of sediments on sea and ocean bottoms: Oceanographia Sinica, v. 9.

Meng, C.Y., 1963, San-i overthrust: Petrol. Geol. Taiwan, no. 2. p. 1-19. 1967, The structural development of the southern half of western Taiwan: Proc. Geol. Soc. China, no. 10, p. 77-82.

Miyabe, Naomi, Hukunaga, Mituo, and Sato, Mitunosuke, 1938, Crustal deformation in Central Taiwan, Part 2: Tokyo Univ. Earthquake Res. Inst. Bull., v. 16, pt. 3, p. 578-596.

Morner, N.A., 1971, Late Quaternary isostatic, eustatic, and climatic changes: Quaternaria, v. 14, p. 65-83. 
Omori, Fusakichi, 1907, Preliminary note on the Formosa earthquake of March 17, 1906: Imp. Earthquake Inves. Comm., Bull., no. 2, 53-69.

Otuka, Yanosuke, 1936, The earthquake of central Taiwan (Formosa), April 21, 1935, and earthquake faults: Tokyo Univ., Earthquake Res. Inst. Bull., Supp. Vol. III, 1936, Papers and reports on the Formosa earthquake of 1935, p. 22-29 (in Japanese; English summary p. 70-74).

Plafker, George, 1969, Tectonics of the March 27, 1964 Alaska earthquake: U.S. Geol. Survey Professional Paper 543-I.

Plafker, George, and Savage, J. C., 1970, Mechanism of the Chilean earthquakes of May 21 and 22, 1960: Geol. Soc. America Bull., v. 81, p. 1001-1030.

Richter, C.F., 1958, Elementary seismology: San Francisco, W.H. Freeman \& Co., 768 p.

Sun, S.C., 1964, Photogeologic study of the Tainan-Kaohsiung coastal plain area, Taiwan: Petrol. Geol. Taiwan, no. 3, p. 39-51. 1965, Geology and petroleum potentialities of the Chingshui-Yuanlin area Taiwan: Petroleum Geol. Taiwan, no. 4, p. 161-173. 1970, Photogeologic study of the Tainan-Hsinying coastal plain, Taiwan: Petroleum Geol. Taiwan, no. 7, p. 133-144.

Sun, S.C., 1971, Photogeologic study of the Hsinying-Chiayi coastal plain, Taiwan: Petroleum Geol. Taiwan, no. 8, P. 65-75. 1972, Photogeologic study of the Peikang-Choshuichi coastal plain, Taiwan: Petroleum Geol. Taiwan, no. 10, p. 187-199.

Taiwan Weather Bureau,[no date], Earthquake report, 1951: Taipei, Taiwan Weather Bureau, 83 p.

Tang, C.H., 1964, Subsurface geology and oil possibilities of the Taoyuan district: Petroleum Geol. Taiwan, no. 3, p. 53-73. 1968, Photogeological observations on the low hilly terrain and coastal plain area of Hsinchu, Taiwan: Petroleum Geol. of Taiwan, no. 6, p. 71-79. 1969, Photogeologic interpretation of the Miaoli area, Taiwan, with special reference to its geologic structures: Geol. Soc. China, Proc., no. 12.

Tarr, R.S., and Martin, Lawrence, 1912, The earthquakes at Yakutat Bay, Alaska, in September, 1899: U.S. Geol. Survey Prof. Paper 69, 135 p.

Tomita, Yosiro, 1955, Some geomorphological considerations to the Chaochou fault in south Taiwan (Formosa), China: Sci. Rep. Tohoku Univ. Geogr., no. 4, p. 58-66.

Tsan, S.F., and Keng, W.P., 1968, The Neogene rocks and major structural features of southwestern Taiwan: Geol. Soc. China Proc., no. 11, p. 45- 59.

U.S. Atomic Energy Commission, 1973, Seismic and geologic siting criteria for nuclear power plants: U.S. Federal Register, v. 38, no. 218, p. 31281- 31285.

Yen, T.P., 1970, Structural analysis of the slate formation of Taiwan: Geol. Survey Taiwan, Bull. no. 21. 